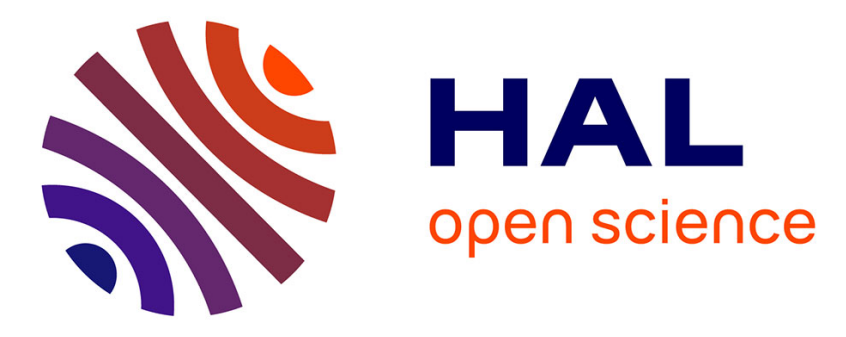

\title{
The impact of agricultural practices on soil biota: a regional study
}

Jean-François Ponge, Guénola Pérès, Muriel Guernion, Nuria Ruiz-Camacho, Jérôme Cortet, Céline Pernin, Cécile Villenave, Rémi Chaussod, Fabrice Martin-Laurent, Antonio Bispo, et al.

\section{To cite this version:}

Jean-François Ponge, Guénola Pérès, Muriel Guernion, Nuria Ruiz-Camacho, Jérôme Cortet, et al.. The impact of agricultural practices on soil biota: a regional study. Soil Biology and Biochemistry, 2013, 67, pp.271-284. 10.1016/j.soilbio.2013.08.026 . hal-00869859

\section{HAL Id: hal-00869859 \\ https://hal.science/hal-00869859}

Submitted on 4 Oct 2013

HAL is a multi-disciplinary open access archive for the deposit and dissemination of scientific research documents, whether they are published or not. The documents may come from teaching and research institutions in France or abroad, or from public or private research centers.
L'archive ouverte pluridisciplinaire HAL, est destinée au dépôt et à la diffusion de documents scientifiques de niveau recherche, publiés ou non, émanant des établissements d'enseignement et de recherche français ou étrangers, des laboratoires publics ou privés. 


\section{The impact of agricultural practices on soil biota: a regional study}

2 Jean-François Ponge ${ }^{\mathrm{a}, *}$, GuénolaPérès ${ }^{\mathrm{b}}$, Muriel Guernion $^{\mathrm{b}}$, Nuria Ruiz-Camacho ${ }^{\mathrm{c}}$, Jérôme

3 Cortet $^{\mathrm{d}, * * *}$, Céline Pernin $^{\mathrm{d}, * * *}$, Cécile Villenave $^{\mathrm{e}, * * * * *}$, Rémi Chaussod $^{\mathrm{f}}$, Fabrice Martin-Laurent $^{\mathrm{f}}$,

$4 \quad$ Antonio Bispo $^{\mathrm{g}}$, Daniel Cluzeau ${ }^{\mathrm{b}}$

a'Muséum National d'Histoire Naturelle, CNRS UMR 7179, 4 avenue du Petit-Château, 91800 Brunoy, France

\section{${ }^{\mathrm{b}}$ Université de Rennes I, CNRS UMR 6553 'EcoBio', OSUR, Station Biologique de Paimpont, 35380}

Paimpont, France

'Institut pour la Recherche et le Développement, UMR 7618 'Bioemco', Centre France-Nord, 32 avenue Henri-Varagnat, 93143 Bondy Cedex, France

${ }^{\mathrm{d}}$ Université de Lorraine,Laboratoire Sols et Environnement,INRA UMR 1120,2 avenue de la Forêt de Haye,54518 Vandouvre-lès-Nancy Cedex, France

${ }^{\mathrm{e}}$ Institut pour la Recherche et le Développement, UMR ECO\&SOLS, 2 place Viala, 34060 Montpellier Cedex 2, France

' Institut National de la Recherche Agronomique, UMR 1347 'Agroécologie', 17 rue Sully, 21065 Dijon Cedex, France

${ }^{\mathrm{g}}$ Agence de l'Environnement et de la Maîtrise de l'Énergie, Centre d'Angers, 20, avenue du Grésillé, BP 90406, 49004 Angers Cedex 1, France

Keywords:agricultural intensity;soil quality index; earthworms; macrofauna; microarthropods;

${ }^{*}$ Corresponding author. Tel.: +33 (0) 678930133; fax: +33 (0) 160465719. E-mail address:ponge@ @mnhn.fr (J.F. Ponge).

${ }^{* *}$ Present address: Université Paul Valéry, UMR 5175, CEFE, Route de Mende, 34000 Montpellier, France

**** Present address: Université de Lille I, Laboratoire Génie Civil \& Géo-Environnement, EA 4515, 59655 Villeneuve d'Ascq Cedex, France

${ }_{* * * * *}$ Present address: ELISOL Environnement, Campus de la Gaillarde, 2 place Viala, 34060 Montpellier Cedex 2, France 
1

nematodes; microbial biomass

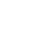

\section{ABSTRACT}

A gradient of agricultural intensification (from permanent meadows to permanent crops, with rotation crop and meadows as intermediary steps) was studied in the course of the RMQS-Biodiv program, covering a regular grid of 109 sites spread over the whole area of French Brittany. Soil biota (earthworms, other macrofauna, microarthropods, nematodes, microorganisms) were sampled according to a standardized procedure, together with visual assessment of a Humus Index. We hypothesized that soil animal and microbial communities were increasingly disturbed along this gradient, resulting in decreasing species richness and decreasing abundance of most sensitive species groups. We also hypothesized that the application of organic matter could compensate for the negative effects of agricultural intensity by increasing the abundance of fauna relying directly on soil organic matter for their food requirements, i.e. saprophagous invertebrates. We show thatstudied animal and microbial groups, with the exception of epigeic springtails, are negatively affected by the intensity of agriculture, meadows and crops in rotation exhibiting features similar to their permanent counterparts. The latter result was interpreted as a rapid adaptation of soil biotic communities to periodic changes in land use provided the agricultural landscape remains stable. The application of pig and chicken slurry, of current practice in the study region, alone or in complement to mineral fertilization, proves to be favorable to saprophagous macrofauna and bacterivorous nematodes. A composite biotic index is proposed to synthesize our results, based on a selection of animals groups which responded the most to agricultural intensification or organic matter application: anecic earthworms, endogeic earthworms, macrofauna other than earthworms (macroarthropods and mollusks), saprophagous macrofauna other than earthworms (macroarthropods and mollusks), epigeic springtails, phytoparasitic nematodes, bacterivorous nematodes and microbial biomass. This composite index allowed scoring land uses and agricultural practices on the base of simple morphological traits of soil animals without identification at species level. 


\section{Introduction}

Soil biota are a major component of agroecosystems, playing a decisive role in ecosystem services such as, among many others, nutrient capture and cycling (Carpenter et al., 2007; Van der Heijden et al., 2008; Murray et al., 2009), building and control of soil organic matter (SOM) or soil physical structure (Wolters, 2000; Jégou et al., 2001; Jouquet et al., 2006), and vegetation dynamics (De Deyn et al., 2003; Mitschunas et al., 2006; Forey et al., 2011), with synergistic effects on crop production (Ingham et al., 1985; Eisenhauer et al., 2010). Studies on plant-soil feedbacks mediated by soil biota showed thatsoil animals and microbes are also involved in signaling processes which contribute to the integrity of agroecosystems and which sustaincrop production (Blouin et al., 2005; Sanon et al., 2009; Endlweber et al., 2011).

Soil biotic communitieswere included in soil quality monitoring programs in Europe, an initiative stimulated byadoption of the Thematic Strategy for Soil Protection by the European Union (EC, 2006), and sets of biological indicators of soil quality were proposed, based on national programs (Black et al., 2003; Rutgers et al., 2009; Keith et al., 2012).In France, the ADEME ("Agence de l'Environnement et de la Maîtrise de l'Énergie") urged scientists to develop tools for monitoring soil quality from a biological point of view and initiated and financially supported the RMQS-BioDiv program in French Brittany, a western peninsula mostly covered with agricultural land.The national RMQS ("Réseau de Mesures de la Qualité des Sols") network (2200 sites, distant of $16 \mathrm{~km}$ ) is devoted to the monitoring of physical-chemical properties of soils (Arrouays et al., 2002; Saby et al., 2011)but with future prospects in soil microbiology (Ranjard et al., 2010). The French Brittany part of this networkwasselected for the assessment of soil biotic communities and the search for a biotic index of soil quality in agricultural land (Cluzeau et al., 2009; Cluzeau et al., 2012; Villenave et al., 2013). microbial communities were selected as a set of indicator groups proposed at European level (Bispo et al., 2009).All of them are known for their sensitivity to disturbances associated to agriculture, among 
1 others tillage (Cortet et al., 2002b; Krogh et al., 2007; Lagomarsino et al., 2009), fertilizer

2 addition(Cole et al., 2005; Van der Wal et al., 2009),pesticide treatment (Frampton, 1997; Rebecchi et

3 al., 2000; Cortet et al., 2002a), disappearance or simplification ofground cover (Filser, 1995;

4 Loranger-Merciris et al., 2006), soil compaction (Cluzeau et al., 1992; Heisler and Kaiser, 1995), and heavy metal contamination (Bruce et al., 1999; Hedde et al., 2012).

Apart from species richness and diversity/evenness indices, widely used at community level, some indices based on species traits directly relevant to disturbance levels were identified for nematodes, such as the Maturity Index (Ettema and Bongers, 1993). Similar indiceshave been proposed for some other invertebrate groups (Parisi et al., 2005) and for the whole faunal community (Yan et al., 2012). Direct extraction of DNA and other standardized microbiological methods also allow estimating parameters of soil biological (mainly microbial) activity (Harris, 2003; Petric et al., 2011). To the study of these taxonomic groups was added a Humus Index, derived from the assessment of biological activity through the identification of humus forms in forest soils (Ponge and Chevalier, 2006), specially adapted to agricultural soils on the base of previous results on the influence of farming systems on soil structure (Topoliantz et al., 2000).

Meadows, meadows in rotation, crop fields in rotation and permanent crop fields can be considered as forming a gradient of increasing intensity of agricultural practices (Burel et al., 1998; Stoate et al., 2001; Decaëns et al., 2008). Our first hypothesis is that increasing disturbance in soil animal and microbial communities can be observed along this gradient, which could be revealed by decreasing species richness and decreasing abundance of more sensitive species groups (Eggleton et al., 2005; Osler and Murphy, 2005).

Some agricultural practices aim at restoring soil fertility, compensating for the exportation of nutrients through herbage and food crop production. Among fertilizing practices, those increasing soil organic matter content, i.e. the application of manure, compost and organic-rich waste products of animal husbandry such as chicken droppings or pig slurry, are known to improve soil quality and crop yield but also lead touncontrolled $\mathrm{N}$ losses (Cox et al., 2001; Antil et al., 2009; Chirinda et al., 2010). 
1 Slurry application may thus compensate for the negative effects of agricultural intensity, in particular

2 for those species relying on soil organic matter ( $\mathrm{SOM}$ ) for food requirements, i.e. saprophages: this is 3 our second hypothesis.

Spatiotemporal influences on the distribution of soil biota (Winkler and Kampichler, 2000;

Decaëns, 2010; Jangid et al., 2011), as well as the effects of geology and related soil features (Kováč, 1994; Popovici and Ciobanu, 2000; Fierer and Jackson, 2006) will be taken into account in our regional scale census of the impact of agricultural practices on soil biotic communities.

\section{Materials and methods}

\subsection{Study sites}

A total of 109 sites, distant of $16 \mathrm{~km}$ on a regular grid, among which 99 in agricultural land (53 crop fields, 46 meadows),were selected for the present study. All these sites pertain to the national RMQS network. They were characterized by geographical position, parent rock and soil type, land use and farming system (Appendix 1). The climate is typically Atlantic but there is a west-east gradient of increasing seasonal contrast and a north-south gradient of increasing temperatureand decreasing rainfall due to mainland effect and Gulf Stream influence, respectively.In French Brittany, most frequent geological substrates are hard rocks such as granite and hard sandstone.

At the time of sampling (2006 and 2007) crop fields were mostly permanent (42 among 53, i.e. $79 \%$ ), while half of the meadows (23 among 46) were included in rotations with crops (Appendix 1). Mineral fertilization was widely used in the studied region (84 sites among 99), alone (20 sites) or more often combined with cattle manure (32 sites), pig and chicken slurry (19 sites) or both (11 sites).

Permanent meadows, meadows in rotation, crops in rotation and permanent crops formed a gradient of agricultural intensity according to increasing use of ploughing, fertilizer and pesticide application: 
- Permanent meadows: no ploughing/tillage or only occasional (when sawn), no or only occasional pesticide application, no fertilizers or varied organic and/or mineral fertilizers, permanent plant cover

- Meadows in rotation: same as above but alternating with crops

- Crops in rotation: same as below but alternating with meadows

- Permanent crops: ploughing/tillage each year (one to three/four times per year), various levels and types of pesticide and fertilizer use, seasonal plant cover

Given the complexity of measuring the impact of pesticides, which may vary in quantity and variety, frequency of application, and ecotoxicity (Sattler et al., 2007), we decided for the present study to note only whether pesticides were used or not, without trying to separate them into categories nor defining any scale of intensity of pesticide use.

\subsection{Sampling procedure}

Sampling took place in 2006 (30 sites) and 2007 (69 sites). With the exception of nonearthworm macroinvertebrates, sampling was done by the same team, previously trained to the different sampling methods in use. Sampling campaigns took place between 15 February and 25 April, the most favorable period in French Brittany agricultural land. Site descriptors were coded and recorded in the DONESOL database (Jolivet et al., 2006a, b).

Sampling plots for soil biota were chosen as near as possible from those previously used for soil description and soil physical-chemical analyses (Arrouays et al., 2002), i.e. $5 \mathrm{~m}$ northward.

Occasional shifts to another direction (west, south, or east) were necessary in cases of unexpected impediment. Sampling plot was a 34 x 3 m stretch of land, homogeneous in plant cover and soil features. This zone was subdivided into elementary sub-plots 1 x 3 m each, identified by stakes of varying color according to soil biota groups, as already described in more detail by Cluzeau et al. (2012). 
Earthworms were sampled in triplicate according to the method devised by Bouché (1972), which was adapted to agricultural context by Cluzeau et al. (1999, 2003).Ten liters of formalin (37\% formaldehyde solution) at $0.25,0.25$ and $0.4 \%$ dilution were watered every 15 min over each elementary 1 x $1 \mathrm{~m}$ quadrat (total surface sampled $3 \mathrm{~m}^{2}$ ). Earthworms expelled to the surface by the irritant solution were collected by hand then preserved in $4 \%$ formalin dilution. After completion of earthworm extraction, a $0.25 \times 0.25 \times 0.25$ soil block was dug up at the center of each quadrat then spread on a plastic sheet, to be sorted by hand for remaining earthworms. Identification was done at species level in the laboratory according to a key (Cluzeau, unpublished, available upon request), based on Bouché (1972). For the present study, the three replicates were compounded in each site. Earthworm species were characterized by abundance and biomass (fresh weight in formalin solution). They were grouped into 'ecological' categories (epigeic, anecic, endogeic) according to Bouché (1972). Earthworm taxonomic (species) richness, diversity (Shannon H') and evenness were calculated on the compound sample (Appendix 2).

Other macroinvertebrates were sampled in six replicates according to the TSBF (Tropical Soil Biology and Fertility) method (Lavelle, 1988; Anderson and Ingram, 1993), modified for temperate soils according to ISO 23611-5 (ISO, 2011). Formalin (0.2\% dilution) was applied every $10 \mathrm{~min}$ on a $25 \times 25 \mathrm{~cm}$ area during half an hour. All macroinvertebrates expelled by the irritant solution (except earthworms) were collected with forceps and preserved in $4 \%$ formalin dilution. A block of soil $15 \mathrm{~cm}$ deep was then dug up to be sorted for all macroinvertebrates visible to the naked eye (except earthworms), which were added to early collected animals. Identification was done at family or above level (Appendix 2). Taxonomic groups were classified in phytophages, saprophages and predators. Macrofauna richness was calculated on one compound sample per site.

Sampling and extraction of microarthropods (springtails, mites) were performed according to ISO 23611-2 (ISO, 2006). Microarthropods were sampled in triplicate with a soil corer, especially designed for the RMQS-BioDiv program, which was forced into the ground. At the inside of the corer three $6 \mathrm{~cm}$-diameter PMMA ('Plexiglas') plastic cylinders allowed to separate three depth levels, 0-5 $\mathrm{cm}, 5-10 \mathrm{~cm}$ and $10-15 \mathrm{~cm}$, which were sent separately to the laboratory for extraction. 
1 Microarthropods were extracted in the plastic cylinders according to the high gradient method (Block, 1966). After extraction, dry samples were sent to another laboratory for the assessment of the Humus Index, as explained below. Springtails (Collembola) were identified to species level while mites (Acari) were classified in Oribatida, Actinedida, Acaridida and Gamasida (suborder level). Microarthropod communities were characterized at taxonomic (taxa, richness, diversity, evenness), functional (life forms: euedaphic, hemiedaphic, epigeic) and demographic level (total abundance of springtails and mites and abundance of mite suborders). The three depth levels and the three replicates were pooled in the present study.

Nematodes were sampled, extracted and identified using ISO 23611-4 (ISO, 2007). For each site, a single sample was composited from 32 samples collected from the surface soil layer $(0-15 \mathrm{~cm})$. The nematodes were extracted from approximately $300 \mathrm{~g}$ wet soil by elutriation, followed by an active passage through a cotton wool filter for 48 hours; they were then counted using a binocular microscope. The composition of the soil nematofauna was determined after fixation in a formaldehyde-glycerol mixture and transfer to mass slides. On average, 200 nematodes per mass slide were identified to family or genus level at $400 \mathrm{X}$ magnification. Genera were grouped in families or sub-families for the present study (Appendix 2). Nematode communities were characterized at taxonomic (taxa, richness, diversity, evenness), functional (sixtrophic groups or functional guilds, nematological indices) and global demographic level (total abundance of nematodes, total abundance of free-living and parasite nematodes). Several indices were used to characterize nematode communities from a functional point of view. The Maturity Index (MI) is based on the successional replacement of colonizers and persisters (corresponding to r- and K-selected life-history strategies) along a c-p scale varying from 1 to 5 (Bongers, 1990;Bongers and Bongers, 1998). MI values increase along successional gradients but this index also measures the level of disturbance of the environment, lower values indicating disturbed environments. It was also calculated separately for free-living, plantparasitic (PPI), bacterial-feeding and fungal-feeding nematodes (Appendix 2). Other functional indicators were used in the present study: Nematode Channel Ratio (NCR), measuring the relative abundance of bacterial-feeders (Yeates, 2003), Structure Index (SI), Enrichment Index (EI) and 
1 Decomposition or Channel Index (DI), measuring environmental stability, resource availability and

2 bacterial activity, respectively (Ferris et al., 2001), and Nematode Damage Index (IP), measuring the

3 impact of nematode pathogens (Dirzo and Domínguez, 1995).

Microbial biomass was measured on an aliquot of a compound sample by the fumigationextraction method (Chaussod et al., 1988), according to ISO 14240-2 (ISO, 1997). DNA was extracted from the soil according to ISO 11063 (ISO, 2012). The proportion of bacterial DNA was calculated by measuring the number of copies of 16S ribosomal DNA (Martin-Laurent et al., 2001).Bacterial functional groups involved in denitrification and degradation of phenolic compounds (involved in the degradation of mineral fertilizers and pesticides, respectively) were estimated by the number of copies of narG and PcaH genes, respectively. The contribution of these two groups to the total bacterial community was estimated by dividing narG and PcaH by $16 \mathrm{~S}$, respectively.

The Humus Index, formerly designed for forest soils (Ponge et al., 2002), was used here as an index of annelid activity, based on previous studies of soil biogenic structures in agricultural soils (Topoliantz et al., 2000).It was visually estimated on soil structure of the dry soil according to a scale varying from 1 (crumby structure, due to earthworm activity) to 3 (compact structure, due to the absence of any visible annelid activity). The intermediate value, 2, corresponds to a spongy structure typical of enchytraeid activity (Topoliantz et al., 2000). For each depth level Humus Index values were averaged among the three replicate samples taken for the extraction of microarthropod fauna. Only mean Humus Index (averaged among the three depth levels $0-5 \mathrm{~cm}, 5-10 \mathrm{~cm}$ and $10-15 \mathrm{~cm}$ ) and surface Humus Index $(0-5 \mathrm{~cm})$ were kept for the present analysis.

\subsection{Data analysis and statistical treatment}

Data were analyzed separately for each group by Redundancy Analysis (RDA), a multivariate regression method, using biotic variables (Appendix 2) as explained variables and 'environmental' variables (land use, practices, geology, year, and geographic position) as explanatory variables (Appendix 1). For the sake of analysis data about agricultural practices were simplified, with 
1 12dummy (presence/absence) variables for land use, fertilizer and pesticide application, direct drilling

2 and litter, one ordinal variable for depth of tillage and one continuous variable for plant cover.

3 Multiple practices (fertilizers, pesticides, etc.) could be combined for the same site by allowing several

4 variables to take 1 as value. Significance of the co-variation between biotic and 'environmental'

5 variables was tested by Monte-Carlo permutation using 500 runs. Partial RDA was used to analyze

6 graphically the influence of land use and agricultural practices upon discarding confounding effects of

7 geology, year and xy position. Most prominent effects depicted by partial RDA were further tested by

8 Mann-Whitney and Kruskal-Wallis non-parametric tests, the latter followed by multiple comparisons

9 among means (two-sided Dunn tests).

Co-variation between the five partial RDAs was tested by calculating the product-moment

(Pearson) coefficient of correlation between site scores along canonical factors of the different

analyses. We also calculated coefficients of correlation (Spearman) between all biological variables

and those biological variables which responded the best to agricultural practices according to RDAs,

using Bonferroni correction for significance level (0.003 in place of 0.05) given the high number of variables to be compared (234). soil biological variables, following the method by Bert et al. (2012).

All calculations were performed with XLSTAT (Addinsoft ${ }^{\circledR}$, Paris, France).

\section{Results}

\subsection{Earthworms}

Permutation tests showed that earthworm communities were significantly affected by land use and agricultural practices upon discarding the effects of geology, year and latitude/longitude (Pseudo$\mathrm{F}=0.6 ; \mathrm{P}<0.0001)$. Figure 1 shows graphically which and how composite variables describing the 
1 earthworm community were influenced by land use and agricultural practices. The first canonical

2 factor (32\% of explained variance) displayed a gradient of increasing anecic abundance and biomass,

3 earthworm species richness and earthworm biomass, corresponding to a land use gradient: permanent

4 crops $\rightarrow$ crops in rotation $\rightarrow$ meadows in rotation $\rightarrow$ permanent meadows. Plant cover increased,

5 while depth of tillage, fertilization (whether mineral or organic) and pesticide use decreased along this

6 gradient of decreasing intensity of agricultural use. The second canonical factor (14\% of explained

7 variance) displayed a gradient of increasing endogeic abundance and biomass, total earthworm

8 abundance, and decreasing earthworm diversity and evenness, according to a gradient of increasing

9 use of pig slurry.

Scores of earthworm species along the first two canonical factors (not shown, available upon request) were in accordance with composite variables. All anecic species increased in abundance along the gradient of decreasing intensity of agricultural use represented by the first canonical factor. The second canonical factor corresponded mainly to the endogeic Nicodrilus caliginosus caliginosus typica, the most abundant and widely represented earthworm species in the studied agricultural crops. application(Table 1). Crop fields (whether permanent or in rotation) exhibited a smaller anecic population size thanmeadows (whether permanent or in rotation). In crop fields, endogeic abundance was doubled by slurry application. Anecic earthworms did not respond significantly to slurry application, although their density was increased. Endogeic earthworms did not respond significantly to agricultural intensification, although they were more abundant in meadows.

\subsection{Macroinvertebrates other than earthworms}

Permutation tests showed that macroinvertebrate communities were significantly affected by land use and agricultural practices upon discarding the effects of geology, year and latitude/longitude (Pseudo-F $=0.68, \mathrm{P}<0.05$ ). Partial RDA showsgraphically (Fig. 2) that abundance of macroinvertebrates, whether total or distributed in guilds (predators, phytophages, saprophages) and 
1 taxonomic richness increased when the intensification of agriculture decreased (same gradient as for

2 earthworms) and plant cover increased accordingly (Factor F1, 34\% of explained variance). The

3 second canonical factor ( $14 \%$ of explained variance) displayed a positive relationship between slurry

4 application and saprophage abundance. Direct drilling was also shown graphically to be positively

5 correlated with saprophage abundance, but this practice was poorly represented in the studied region

6 (9 sites, compared to 19 sites for slurry application), making conclusions for direct drilling less sure

7 than for slurry application.

With the exception of millipedes (Iulidae, Polydesmidae, Glomeridae), all soil macroarthropod and mollusk (slugs and snails) taxa responded negatively to increased intensification of agriculture (F1). Tipulid larvae were dominant in abundance among the saprophagous macroarthropod and mollusk taxa which responded positively to slurry application (F2).

Like anecic earthworms, densities of other macroinvertebrates declined in crops, whether permanent or in rotation, compared with permanent meadows (Table 1). Although not dominant in numbers among macroinvertebrates, saprophages shared thisgeneral trend. Total densities of macrofauna of crops (permanent and in rotation) increased in the presence of slurry, but this increase was even more prominent in saprophages.

\subsection{Microarthropods}

Permutation tests showed that microarthropod communities were significantly affected by land use and agricultural practices upon discarding the effects of geology, year and latitude/longitude (Pseudo-F $=1, \mathrm{P}<0.0001)$. The first canonical factor $(\mathrm{F} 1,21 \%$ of total variance) represented a gradient of increasing abundance of total mesofauna as well as of its two main component groups, mites and springtails (Fig. 3). With the exception of epigeic springtails, all microarthropod groups increased in abundance (although not in richness, diversity and evenness) along F1. The first canonical factor did not display a gradient of decreasing intensification of agriculture, meadows in rotation (on the positive side, i.e. maximizing microarthropod densities) being opposed to permanent meadows and 
1 crops in rotation on the negative side of F1. The contrast between crops and meadows, associated with

2 a corresponding increase in plant cover, was represented by the second canonical factor F2, crops

3 (permanent and in rotation) maximizing densities of epigeic springtails as well mesofaunal richness,

4 diversity and evenness, opposite to permanent meadows, meadows in rotation being in intermediary

5 position. The second canonical factor expressed also a contrast between mites and springtails

6 according to plant cover, abundance of oribatid mites being associated with increased plant cover on

7 the negative side of F2. Slurry application did not exhibit any clear trend in microarthropod

8 community parameters.

With the exception of Lepidocyrtus lignorum and Sphaeridia pumilis, all epigeic springtail species followed the general trend displayed by F2, i.e. they increased in density with intensification of agriculture. Epigeic springtails were five times more abundant in permanent crops than in permanent meadows (Table 1), while oribatid mites displayed an opposite (although not significant) pattern (data not shown).

\subsection{Nematodes}

Permutation tests showed that nematode communities were significantly affected by land use and agricultural practices upon discarding the effects of geology, year and latitude/longitude (pseudo-F $=1.1, \mathrm{P}<0.0001)$. According to the first canonical factor $\mathrm{F} 1$ (35\% of explained variance), the gradient of decreasing intensification of agriculture from permanent crops to permanent meadows maximized the number of phytoparasites, the total abundance of nematodes, the Maturity Index MI, and minimized the Enrichment Index EI and the Decomposition or Channel Index DI (Fig. 4). As for earthworms and other macrofauna, the second canonical factor corresponded to slurry application. When analyzed graphically, this practice tended to maximize the Decomposition or Channel Index DI, the Nematode Channel Ratio NCR, the density of pioneer bacterivores (c-p 1 group), and more generally free-living nematodes, and minimized the Bacterivore Maturity Index. 
The abundance of phytoparasites decreased regularly along the gradient of intensification of agriculture, being divided by three in permanent crops compared to permanent meadows (Fig. 8a, Table 1), while phytoparasites did not respond to slurry application (Table 1). There was a significant (although not very pronounced) increase in the abundance of bacterivores in the presence of slurry application, while this feeding categorydid not respond to land use. Land uses were not discriminated when r-selected (c-p-1) and K-selected (c-p-2-3-4) groups of bacterivorous nematodes were analyzed separately (data not shown), although c-p-2-3-4 bacterivores seemed to react negatively to increased intensification of agriculture, as suggested by Figure 4.

\subsection{Microbial communities}

Permutation tests showed that microbial communities were significantly affected by land use and agricultural practices upon discarding the effects of geology, year and latitude/longitude (Pseudo$\mathrm{F}=0.36, \mathrm{P}<0.01)$. The first canonical factor $\mathrm{F} 1$ (65\% of the explained variance) corresponded to a gradient of increasing microbial biomass (whether expressed per unit soil or carbon weight) according to decreasing intensification of agriculture (Fig. 5). The second canonical factor F2 (19\% of explained variance) did not exhibit any clear environmental trend, neither in land use nor in agricultural practices, and could not be interpreted with accuracy: the position of narG/16S and PcaH/16S far from the origin along F2 indicated that there was a gradient among the study sites in the contribution of denitrifiers and protocatechuate degraders to the bacterial community, which could not be explained by agricultural practices.

There was a good agreement between microbial biomass and the level of intensification of agriculture: microbial biomass decreased regularly along the gradient permanent meadows $\rightarrow$ meadows in rotation $\rightarrow$ crops in rotation $\rightarrow$ permanent crops, while not responding to slurry application (Table 1). The second canonical axis corresponded to variable proportions of bacterial functional groups but without any marked links with agricultural practices. 
1

3

4

5

6 $7=0.84)$.
9

\subsection{Humus Index}

Permutation tests showed that the Humus Index was not significantly affected by land use and agricultural practices upon discarding the effects of geology, year and latitude/longitude (Pseudo-F = $0.024, \mathrm{P}=0.35$ ), thus the null hypothesis was accepted. Examination by total RDA of subsets of the 'environmental' matrixrevealed a significant geologic signal (Pseudo- $\mathrm{F}=0.44, \mathrm{P}<0.01$ ), a marginally significant geographic signal (Pseudo-F $=0.06, P=0.058$ ) and a nil year signal (Pseudo-F $=0.002, P$

\subsection{Co-variation between biotic components}

Based on results of separate multivariate analyses the first canonical factor was selected as corresponding to the gradient of agricultural intensity for earthworms, macrofauna other than earthworms, nematodes and microbes, while the same gradient was represented by the second canonical factor for microarthropods. Table 2 shows that the ordination of agricultural sites co-varied at a high level of significance $(\mathrm{P}<0.0001)$ in the separate analyses performed on different animal and microbial groups. In absolute value the product-moment correlation coefficient varied from 0.41 (macrofauna other than earthworms versus microarthropods) to 0.86 (earthworms versus microbes). Negative values (for microarthropods) indicate that the gradient from meadows to crop fields was inverted compared to the four other groups. Mesofaunal richness, diversity, and evenness were on the positive side of F2 (Fig. 3), i.e. favored by agricultural intensity (crop fields), while the contrary was shown for earthworms (Fig. 1) and macrofauna other than earthworms (Fig. 2).

The second canonical factors of partial RDAs corresponded to slurry application for earthworms, macrofauna other than earthworms and nematodes. These three factors were positively correlated (Table 3), at a higher level of significance between nematodes and earthworms or macrofauna than between earthworms and macrofauna: endogeic earthworms, saprophagous macrofauna and bacterivorous nematodes reacted positively and in a coordinated manner to slurry application. 
Anecic abundance was positively correlated with earthworm abundance, biomass, species richness and diversity $\left(r_{\mathrm{s}}=0.57,0.84,0.55\right.$ and 0.51 , respectively; $\left.\mathrm{P}<0.0001\right)$, anecic biomass $\left(\mathrm{r}_{\mathrm{s}}=\right.$ $0.89, \mathrm{P}<0.0001)$, epigeic abundance and biomass $\left(\mathrm{r}_{\mathrm{s}}=0.37\right.$ and 0.40 , respectively; $\mathrm{P}<0.001$ in both cases $)$ and endogeic biomass $\left(r_{s}=0.39 ; P<0.001\right)$. In the macrofauna community anecic abundance was positively correlated with the abundance of saprophagous tipulid larvae $\left(r_{s}=0.40, P<0.001\right)$. In the microarthropod community anecic abundance was negatively correlated with the abundance of epigeic springtails and that of the epigeic Isotomurus gr. palustris $\left(\mathrm{r}_{\mathrm{s}}=-0.38\right.$ and -0.34 , respectively; $\mathrm{P}$ $<0.001$ and 0.01 , respectively). In the nematode community anecic abundance was positively correlated with the Plant Parasite Index (PPI), the abundance of phytoparasites $\left(r_{s}=0.36\right.$ and 0.44 , respectively; $\mathrm{P}<0.001$ and 0.0001 , respectively), and the abundance of the phytoparasitic Meloidogynae $\left(r_{s}=0.44, P<0.0001\right)$. No significant correlation was found with microbial parameters. Endogeic abundance was positively correlated with earthworm abundance and biomass $\left(\mathrm{r}_{\mathrm{s}}=\right.$ 0.89 and 0.55 , respectively; $\mathrm{P}<0.0001$ in both cases), endogeic biomass $\left(\mathrm{r}_{\mathrm{s}}=0.91 ; \mathrm{P}<0.0001\right)$ and abundance of the anecic Lumbricus terrestris $\left(\mathrm{r}_{\mathrm{s}}=0.37 ; \mathrm{P}<0.001\right)$. In the macrofauna community, endogeic abundance was positively correlated with the abundance of phytophages $\left(\mathrm{r}_{\mathrm{s}}=0.37\right.$; $\mathrm{P}$ 0.001). No correlation was found between endogeic abundance and microarthropod, nematode or microbial parameters.

The abundance of macrofauna other than earthworms was positively correlated with earthworm species richness $\left(\mathrm{r}_{\mathrm{s}}=0.37 ; \mathrm{P}<0.01\right)$ and with the abundance and biomass of epigeic earthworms ( $\mathrm{r}_{\mathrm{s}}=0.41$ and 0.43 , respectively; $\mathrm{P}<0.001$ in both cases). In the macrofauna community, if we discard trivial relationships with groups included in its calculation, the abundance of macrofauna was positively correlated with macrofaunal taxonomic richness $\left(\mathrm{r}_{\mathrm{s}}=0.57 ; \mathrm{P}<0.0001\right)$. In the microarthropod community, the abundance of macrofauna was negatively correlated with the abundance of the epigeic springtail Isotomurus gr. palustris $\left(\mathrm{r}_{\mathrm{s}}=-0.38 ; \mathrm{P}<0.001\right)$. In the nematode community the abundance of macrofauna was negatively correlated with the Decomposition Index (CI) $\left(\mathrm{r}_{\mathrm{s}}=-0.35 ; \mathrm{P}<0.01\right)$. The abundance of macrofauna other than earthworms was positively 
1 correlated with microbial biomass, either calculated per unit soil mass or per unit carbon $\left(\mathrm{r}_{\mathrm{s}}=0.41\right.$ and

20.43 , respectively; $\mathrm{P}<0.001$ in both cases).

The abundance of saprophagous macrofauna other than earthworms was positively correlated with the abundance and biomass of epigeic earthworms $\left(\mathrm{r}_{\mathrm{s}}=0.37 ; \mathrm{P}<0.01\right.$ in both cases $)$. Within the macrofauna community it was positively correlated with phytophagous, predator and, as expected, total abundance of macrofauna $\left(\mathrm{r}_{\mathrm{s}}=0.42,0.49\right.$ and 0.63 , respectively; $\mathrm{P}<0.001$ and $<0.0001$ in the two latter cases). The abundance of saprophagous macrofauna was also positively correlated with macrofaunal taxonomic richness $\left(\mathrm{r}_{\mathrm{s}}=0.69 ; \mathrm{P}<0.0001\right)$. In the microarthropod community it was negatively correlated with the abundance of the epigeic springtail Isotomurus gr. palustris $\left(\mathrm{r}_{\mathrm{s}}=-0.42\right.$; $\mathrm{P}<0.001)$. In the nematode community the abundance of saprophagous macrofauna was positively correlated with the Maturity Index (MI), the Maturity Index without phytoparasites and the Bacterivore Maturity Index (BaMI) $\left(r_{s}=0.37,0.37\right.$ and 0.35, respectively; $\mathrm{P}<0.01$ in all cases), and was negatively correlated with the Enrichment Index $(E I)\left(r_{s}=-0.37 ; P<0.001\right)$. In the microbial community the abundance of saprophagous macrofauna was positively correlated with microbial biomass, either calculated per unit soil mass or per unit carbon $\left(r_{s}=0.35\right.$ and 0.37 , respectively; $\mathrm{P}<$ 0.01 and 0.001 , respectively), and with the abundance of denitrifiers (narG) $\left(\mathrm{r}_{\mathrm{s}}=0.34 ; \mathrm{P}<0.01\right)$.

The abundance of epigeic springtails was negatively correlated with earthworm species richness and diversity $\left(r_{s}=0.38\right.$ and 0.34 , respectively; $P<0.001$ and 0.01 , respectively) and with the abundance of anecic earthworms $\left(\mathrm{r}_{\mathrm{s}}=0.34 ; \mathrm{P}<0.01\right)$. In the macrofauna community, it was negatively correlated with macrofaunal taxonomic richness and abundance of phytophages $\left(r_{s}=-0.38\right.$ and -0.39 , respectively; $\mathrm{P}<0.001$ in both cases) and with the abundance of ants and woodlice $\left(\mathrm{r}_{\mathrm{s}}=-0.41 ; \mathrm{P}<\right.$ 0.001 in both cases). Within the microarthropod community, the abundance of epigeic springtails was positively correlated with total springtail abundance $\left(\mathrm{r}_{\mathrm{s}}=0.53 ; \mathrm{P}<0.0001\right)$, and total mesofaunal abundance, taxonomic richness and diversity $\left(\mathrm{r}_{\mathrm{s}}=0.44,0.49\right.$ and 0.37 , respectively; $\mathrm{P}<0.0001$, < 0.0001 and 0.01 , respectively). In the microbial community it was negatively correlated with the microbial biomass per unit carbon $\left(\mathrm{r}_{\mathrm{s}}=-0.38 ; \mathrm{P}<0.001\right)$. No significant correlation was observed with nematode parameters. 
The abundance of phytoparasitic nematodes was positively correlated with earthworm biomass and species richness $\left(\mathrm{r}_{\mathrm{s}}=0.38\right.$ and 0.35 , respectively; $\mathrm{P}<0.001$ and 0.01 , respectively) and with anecic biomass $\left(\mathrm{r}_{\mathrm{s}}=0.36 ; \mathrm{P}<0.01\right)$. In the microarthropod community it was negatively correlated with the abundance of the epigeic springtail Isotomurus gr. palustrisand that of the endogeic springtail Mesaphorura hylophila $\left(\mathrm{r}_{\mathrm{s}}=-0.39\right.$ and -0.37 , respectively; $\mathrm{P}<0.001$ and $<0.01$, respectively). Within the nematode community, if we discard trivial relationships with members of this trophic group, the abundance of phytoparasites was positively correlated with the Maturity Index with (MI) or without phytoparasites ( $\mathrm{r}_{\mathrm{s}}=0.52$ and 0.50 , respectively; $\mathrm{P}<0.0001$ in both cases), with the Bacterivore Maturity Index $(\mathrm{BaMI})\left(\mathrm{r}_{\mathrm{s}}=0.46 ; \mathrm{P}<0.0001\right)$, and negatively with the Enrichment Index $(\mathrm{EI})\left(\mathrm{r}_{\mathrm{s}}=-\right.$ $0.41 ; \mathrm{P}<0.001$ ). The abundance of phytoparasitic nematodes (per unit soil weight, as for all nematode parameters) was positively correlated with the microbial biomass per unit soil weight $\left(\mathrm{r}_{\mathrm{s}}=0.39 ; \mathrm{P}<\right.$ 0.001). No significant correlation was observed with macrofaunal parameters.

The abundance of bacterivorous nematodes was not correlated with any parameters of the macrofauna community (earthworms included). In the microarthropod community it was positively correlated with the abundance of gamasid mites, a predatory group $\left(\mathrm{r}_{\mathrm{s}}=0.42 ; \mathrm{P}<0.001\right)$, and that of Isotomiella minor, an endogeic springtail $\left(\mathrm{r}_{\mathrm{s}}=0.35 ; \mathrm{P}<0.01\right)$. Within the nematode community, after discarding trivial results, the abundance of bacterivorous nematodes was positively correlated with the Nematode Channel Ratio (NCR) and the Decomposition Index (CI) $\left(\mathrm{r}_{\mathrm{s}}=0.42\right.$ and 0.39 , respectively; P $<0.001$ in both cases). No correlation was observed with any microbial parameters.

The microbial biomass per unit soil weight was positively correlated with earthworm biomass and taxonomic richness $\left(\mathrm{r}_{\mathrm{s}}=0.41\right.$ and 0.38 , respectively; $\mathrm{P}<0.001$ in both cases $)$ and with anecic biomass $\left(\mathrm{r}_{\mathrm{s}}=0.34 ; \mathrm{P}<0.01\right)$. It was also positively correlated with the abundance of non-earthworm macrofauna, whether total or restricted to saprophages $\left(\mathrm{r}_{\mathrm{s}}=0.41\right.$ and 0.35 , respectively; $\mathrm{P}<0.001$ and $<0.01$, respectively). In the microarthropod community, it was negatively correlated with the abundance of the epigeic springtail Isotomurus gr. palustris $\left(\mathrm{r}_{\mathrm{s}}=-0.39 ; \mathrm{P}<0.001\right)$ and positively with that of the epigeic springtail Sphaeridia pumilis $\left(\mathrm{r}_{\mathrm{s}}=0.41 ; \mathrm{P}<0.001\right)$. In the nematode community, microbial biomass per unit soil weight was positively correlated with total nematode abundance and 
1 taxonomic richness $\left(\mathrm{r}_{\mathrm{s}}=0.37\right.$ and 0.38 , respectively; $\mathrm{P}<0.01$ and $<0.001$, respectively), with the

2 abundance of phytophagous and omnivorous nematodes $\left(\mathrm{r}_{\mathrm{s}}=0.39\right.$ and 0.43 , respectively; $\mathrm{P}<0.001$ in

3 both cases), with the Maturity Index (MI), the Maturity Index without phytoparasites and the

4 Bacterivore Maturity Index (BaMI) $\left(r_{s}=0.45,0.46\right.$ and 0.41 , respectively; $\mathrm{P}<0.0001,<0.0001$ and

50.001 , respectively) and was negatively correlated with the Enrichment Index $(E I)\left(r_{s}=-0.38 ; P<\right.$

$6 \quad 0.001)$.

\subsection{A composite biotic indicator of agroecosystems for French Brittany}

Results presented in Table 1 allow ranking agricultural usages from 1 to 4 taking into account 8 biotic groups: anecic earthworms, endogeic earthworms, macrofauna other than earthworms (macroarthropods and mollusks), saprophagous macrofauna (macroarthropods and mollusks), epigeic springtails, phytoparasitic nematodes, bacterivorous nematodes, and microbial biomass. Some groups responded significantly to land use type (permanent meadows, meadows in rotation, crops in rotation, permanent crops), others to slurry application, a fertilizing practice widely used in the studied region. These ranks were averaged per column, giving a rank score to each land use type and to each agricultural practice from French Brittany. Here only slurry application was addressed among agricultural practices, since most studied groups exhibited a clear slurry application signal in Redundancy Analysis. Note that according to this method of calculation the lower the rank score, the higher the biotic improvement, and that no statistical testing of the observed differences is possible.

According to this composite biotic indicator, the gradient of intensity of agriculture exhibited an array of scores ranging from 1.8 for permanent meadows (the 'best' land use from the point of view of selected soil biota) to 3.1 for permanent crops. The increase from permanent meadows (1.8) to meadows in rotation (2.1) was weak, as was the increase from crops in rotation (3.0) to permanent crops (3.1). The impact of slurry (1.4 for slurry against 1.6 for no slurry) was weak. 


\section{1}

\section{Discussion}

\subsection{Groups which responded negatively to agricultural intensity}

We showed that a variety of animal and microbial groups were negatively affected by the intensity of agriculture, from permanent meadows to permanent crops, while meadows and crops in rotation exhibited intermediary features, thereby supporting our first hypothesis.

The 56\% decrease in microbial biomass observed along our gradient of agricultural intensity (Table 1), a decrease oftenreported in a wide range of agroecosystems (Fließbach et al., 2007; Lagomarsino et al., 2009; Jangid et al., 2011), has been mainly explained by a decrease in soil organic matter: more plant biomass is exported through crop yields, vegetation covers the ground over a shorter period and tillage decreases SOM poolsto a greater extent in crop fields when compared to meadows (Duxbury et al., 1989; Lagomarsino et al., 2009).Complementary data on our study sites (Appendix 3) showed that organic carbon and total nitrogen decreased by 28 and 25\%, respectively, and plant cover was divided by two from permanent meadows to permanent crops. A clear positive relationship between microbial biomassand SOMcontent has been established in agricultural soils by Insam and Domsch (1988) and has been widely reported since then (Nair and Ngouajio, 2012).

By being at the base of soil trophic networks, microbial biomass controls the development of all organisms ingesting it directly or indirectly, i.e. saprophages(including microbivores) and, by chain reaction, predators (Ponsard et al., 2000). However, microbial biomass is in turn controlled by the activity of soil engineers (earthworms in our temperate context) and litter animal decomposers (millipedes, woodlice, tipulid larvae, etc.) which are involved in mutual relationships with microbial communities (Lavelle et al., 2006; Ponge, 2013). This was reflected inthe positive relationships between microbial biomass and biomass and taxonomic richness of earthworms, abundance of macrofauna other than earthworms, abundance and taxonomic richness of nematodes. Decreases in densities and species richness of macroinvertebrates, whether saprophagousor predatory, have been noted along intensification gradients (Eggleton et al., 2005; Postma-Blaauw et al., 2010, 2012). We also showed that macroinvertebrates were severely affected by agricultural intensity, while 
1 bacterivorous nematodes (the dominant trophic group of nematodes) were not affected at all (Table 1).

2 Co-variation analyses on our data showed that microbial biomass was positively correlated with the

3 abundance of phytophagous and omnivorous nematodes, but not with that of bacterivorous nematodes,

4 and was positively correlated with several nematological indices indicating maturation of the community to the expense of pioneer bacterivores. This result could be compared with a study done in

6 the Netherlands by Postma-Blaauw et al. (2010, 2012), who showed that bigger-sized animals were more affected by agricultural intensity than smaller-sized animals. They attributed this difference to the impact of mechanical disturbance on bigger-sized animals, which adds another mechanism to the disturbance caused by shortage in microbial biomass. Negative effects of plant species rarefaction on soil microbial communities have been also experimentally demonstrated (Loranger-Merciris et al., 2006), as well as the sensitivity of microbial biomass to pesticide use (Harden et al., 1993) and agricultural traffic (Heisler and Kaiser, 1995).

Other factors,such as the development of root systems,involved in mutualisms with soil microbial and animal communities (Heil, 2011; Ponge, 2013), should also be taken into account to explain the observed negative response of soil biota to agricultural intensity (Ingham et al., 1985; Alphei et al., 1996; Bonkowski et al., 2000), although we did not provide data about it, except indirectly through the plant cover, which was divided by two from meadows to crop fields (Appendix 3), and the abundance of phytoparasite nematodes, which was divided by three along the same gradient (Table 1). Root biomass is known to be higher and more stable over seasons in perennial compared to annual crops (Zan et al., 2001), which may explain, together with the current use of nematicides in annual crops, the pattern we observed in phytoparasitic nematodes, a result already reportedby Yeates and Bird (1994), but not retrieved in the experiment by Postma-Blaauw et al. (2010). As for other results of co-variation analyses, it should be noted that the positive relationship observed along our gradient of agricultural intensity between the abundance of anecics and that of phytoparasites (and associated nematological indices) was probably due to common trends in requirements of these animals more than to positive direct or indirect interactions between them. 


\subsection{Groups which responded positively to agricultural intensity}

The case of epigeic springtails should be considered apart, since these animals are living at the soil surface and on low vegetation (Frampton et al., 2001) and thus do not respond to the same constraints as soil-dwelling biota, even thoughcollected in the same core samples. Epigeic springtails are very mobile animals (Frampton et al., 2001) which are able to find refuges within or in the vicinity of agricultural fields and may recolonize after the field has been disturbed by agricultural traffic or spraying(Mebes and Filser, 1997; Alvarez et al., 1997, 2000).However, this does not explain why they were comparatively disfavored in meadows, in particular in permanent meadows, compared to annual crops (Filser et al., 2002). Possible reasons are the lower density level of surface predators such as carabids and spiders underintensive agriculture (supported by our results, see Fig. 2), a reason invoked to explain the rapid recovery of epigeic springtail populationsafter insecticide application (Duffield and Aebischer, 1994), and the detrimental effects of grazing pressure (Dombos, 2001; Petersen et al., 2004).Co-variation analyses did not throw any light on possible relationships between epigeic springtails and their predators, to the exception of a negative relationship with ants. It must be noticed that the observed decrease in the abundance of epigeic springtails in permanent meadows, compared to permanent and rotation crops, conflicts at first sight with results obtained in Germany (86 sites) by Chauvat et al. (2007), who showed that the abundance of springtails increased from permanent crop fields to meadows and increased then decreased according to the age of meadows. However, examination of their data (Table 2 in Chauvat et al., 2007) showed that the two most common epigeic species of crop fields (Isotoma viridis, Lepidocyrtus lanuginosus), which made the bulk of their epigeic group, were more abundant in permanent crop fields than in old meadows (> 40 years), thereby explaining apparent disagreement between our results and theirs.

The increase of mesofaunal richness, diversity and evenness, observed along our gradient of agricultural intensity, contrasts with the decrease of species richness observed in macrofauna. This might indicate either opposite trends in microarthropods (to the exception of oribatid mites, see Fig. 3) and macroinvertebrates in their response to agricultural intensity, or negative interactions between organisms of various sizes. It should be noted that the latter pattern could be revealed only by 
1 comparing samples within sites, or by discarding site effects, which was not possible with our data,

2 since microarthropods, macroinvertebrates and microbial communities were not studied on the same

3 samples. The pattern observed with epigeic springtail species, in particular Isotomurus gr. palustris,

4 which displayed negative relationships with the abundance of macroinvertebrates, whether saprophagous, predatory or phytophagous, is probably explained more by opposite trends according to agricultural intensity than by negative interactions. Published studies where microarthropods and macroinvertebrates were sampled together rather indicate positive interactions between Collembola (and their mesostigmatid mite predators) and earthworms (Marinissen and Bok, 1988; Hamilton and Sillman, 1989; Loranger et al., 1998, Maraun et al., 1999), explained by direct favorable trophic influences (Salmon, 2004; Monroy et al., 2011; Guttiérrez-López et al., 2011) and ecosystem engineering (Marinissen and Bok, 1988; Hamilton and Sillman, 1989; Maraun et al., 1999; Eisenhauer, 2010). In the present study we did not find such a positive relationship but, as mentioned above, only within-site comparisons should be acceptable in this context.

\subsection{Groups which did not respond to agricultural intensity}

Endogeic earthworms did not respond to agricultural intensity while anecic earthworms did: theydecreased in density, but not significantly and not to the same extent as anecic worms. This can be explained by the higher sensitivity of anecic earthworms to conventional cropping systems(Lamandé et al., 2003; Krogh et al., 2007; Pelosi et al., 2009), due to differential impactson this ecological category of agricultural traffic (Pižl, 1992),ploughing (Edwards and Lofty, 1975; Wyss and Glasstetter, 1992) and pesticide use (Wright, 1977), although some studies did not conclude to any detrimental effect of deep tillage on anecics in maize crops (Debeljak et al., 2007). This result contradicts common tenets about life-history strategies in lumbricid worms (Satchell, 1980), since Kselected endogeic worms seem to be better adapted to disturbance than r-selected anecic worms.

The case of bacterivorous nematodes (in particular the c-p-1 r-selected guild) is less easy to explain, because they should be directly affected by the dramatic decrease in microbial biomass which 
1 was observed along the studied gradient of agricultural intensification (Freckman, 1988). However, we

2 did not register any correlation between the abundance of bacterivorous nematodes and any of the

3 studied microbial parameters, nor with macrofaunal parameters. A weaker response of bacterivorous

4 nematodes compared to bigger-sized saprophages has been also reported by Postma-Blaauw et al.

$5(2010,2012)$.

The Humus Index (Ponge et al., 2002; Ponge and Chevalier, 2006) can be ruled out as a means to assess the impact of agricultural intensification on soil biota, given its too high sensitivity to geology. In particular, the dominance of sand-size fractions may impede to adequately record fine spongy structures created by enchytraeid worms when compared to compact soils deprived of biogenic structures (Topoliantz et al., 2000).

\subsection{Responses of soil biota to slurry application}

Slurry application elicited a positive response of some biota, in particular endogeic earthworms, bacterivorous nematodes and macrofauna relying on SOM, i.e. saprophages, supporting our second hypothesis. Above all, the richness of chicken and pig slurry in easily degraded or directly assimilated nitrogenous and carbonaceous compounds must be thought responsible for the observed effects (Jensen et al., 2000). Endogeic earthworms are favored by easily degradable and nitrogen-rich organic matter (Zajonc, 1975; Tiunov and Scheu, 2004; Van Eekeren et al., 2009), while bacterivorous nematodes are favored by labile compounds in slurry (De Goede et al., 2003; Van Eekeren et al., 2009). The case of other macrofauna (saprophagous or predatory) is less easy to explain, although they may benefit from the presence of coarse organic matter in applied slurries (Sasada et al., 2011).

Otherindirect effects can be suspected, too, such as the ingestion of nematodes (Hyvönen et al., 1994; Monroy et al., 2008).

\subsection{The composite biotic indicator}


Direct and indirect effects of land use and agricultural practices on soil biota were synthesized

2 in a composite biotic indicator, which was used to compare farming systems of French Brittany by

3 aggregate rank scores. We showed that the intensity of agriculture, from permanent meadows to permanent crop fields, passing by rotation fields in intermediary position, exerted unfavorable effectson soil biota, and this for a variety of reasons, which all tend to impoverish and simplify soil trophic networks: decrease of plant cover, decrease in microbial biomass and SOM content, increase in intensity and frequency of mechanical disturbance, and pesticide use (Duxbury et al., 1989).

The observed similarity in composite rank scores between permanent land uses and those included in rotationsis worth of notice. It seems to indicate that in the studied region soil communities (i) adapt rapidly to changes in land use in agricultural land, at least at the level of broad taxonomic groups, and (ii) are not favored by rotation itself. This contradicts, at least at first sight, studies showing that soil animal communities lag behind rapid shifts in plant communities observed after land use change from forest to agricultural land, and the reverse (Kardol et al., 2005; Ponge et al., 2006). This might indicate that $(i)$ meadows and crop fields do not differ to a so great extent, crop fields being, at least from the point of view of soil biota, nothing else than an impoverished variant of meadows (Postma-Blaauw et al., 2012), and (ii)soil biodiversity of agroecosystemsmay recover rapidly once main stress factors (lack of plant cover and soil organic matter, pesticide use, mechanical disturbance) are definitively or temporarily alleviated (Postma-Blaauw et al., 2010). However, it must be noticed that Postma-Blaauw et al. (2012) showed that rapid recovery of invertebrate communities after conversion of cropland to grassland did not occur in predatory mites and enchytraeids.

We must now question the generality of the proposed composite biotic indicator of agricultural soil quality. First, it is based on a regional study, thus over a restricted array of climate, geologic and historical conditions, such as that found in French Brittany. Second, the proposed selection of faunal and microbial variables (Table 1) may differ according to the purpose of biotic indication: clearly it does not apply to the assessment of soil health in industrial, urban or forest soils. Admittedly, it should 
Other soil fauna indices of soil quality, based either on the presence/absence (Parisi et al.,

2 2005) or on the abundance of species (Cortet et al., 2002b; Ruiz et al., 2011; Yan et al., 2012) have been proposed and were tested on various agricultural sites. Both Parisi' and Yan' indices weight the species by their functional traits, as does the Maturity Index for nematodes. However, all these indices are based on complete identification at species level of a large array of taxonomic groups, a timeconsuming step, while our composite biotic index did not necessitate so a fine resolution, most indicator groups listed in Table 1 being easy to record without resorting to specialists. Other indices are similarly based on wide taxonomic groups, easy to identify, but they include also variables describing the physical and chemical state of the soil (roughly speaking, soil fertility). The best example is the GISQ multifactorial indicator of soil quality proposed by Velasquez et al. (2007), based on a set of 5 sub-indicators further combined in a single general indicator of soil quality.One of the sub-indicators is devoted to macrofauna and could be used independently of the others. Another biotic indicator, BISK, reaching a level of model complexityand universality similar to GISQ, has been proposed within the Netherlands Monitoring Network (Rutgers et al., 2009). Here too, soil characteristics are incorporated into the composite indicator, in particular heavy metals and pesticides, which evidently have a prominent importance in the impact of agricultural practices on soil organisms. However we suspect that incorporating in BISK some soil characteristics which are directly under the influence of human practices will increase artificially the chance to find statistically significant impacts of human activities on soil quality. This is the reason why we suggest to consider only biota (and preferably a limited array of easily identifiable organisms or bulk biological variables such as microbial biomass) in a composite indicator of soil 'health' and to detect community changes after discarding the influence of factors not directly influenced by human activities. Given the abovementioned limits of our composite indicator, we consider it as a mean to synthesize our results in a regional context. This does not preclude any endeavor towards building a universal index of soil quality which includes soil biota, a wish shared since a long-time by the community of soil biologists.

\section{Acknowledgements}


1 Many people, owners, farmers, students, and technicians, were involved in the selection and disposal

2 of sites, of sampling material, sampling process, transport and identification. They are collectively

3 acknowledged. Without their help, nothing would have been made possible. The authors acknowledge

4 the "Agence de l'Environnement et de la Maîtrise de l'Énergie" (ADEME) for incitation and financial

5 support, and Laurence Rougé for conception of the RMQS-Biodiv database and fruitful interaction

$6 \quad$ with the participants.

\section{References}

Alphei, J., Bonkowski, M., Scheu, S., 1996. Protozoa, Nematoda and Lumbricidae in the rhizosphere of Hordelymuseuropaeus (Poaceae): faunal interactions, response of microorganisms and effects on plant growth. Oecologia 106, 111-126.

Alvarez, T., Frampton, G.K., Goulson, D., 1997. Population dynamics of epigeic Collembola in arable fields: the importance of hedgerow proximity and crop type. Pedobiologia 41, 110-114.

Alvarez, T., Frampton, G.K., Goulson, D., 2000. The role of hedgerows in the recolonisation of arable fields by epigeal Collembola.Pedobiologia 44, 516-526.

Anderson, J.P.E., Ingram, J.S.I., 1993. Tropical Soil Biology and Fertility.A Handbook of Methods. CAB International, Oxon.

Antil, R.S., Janssen, B.H., Lantinga, E.A., 2009. Laboratory and greenhouse assessment of plant availability of organic $\mathrm{N}$ in animal manure.Nutrient Cycling in Agroecosystems 85, 95-106.

Arrouays, D., Jolivet, C., Boulonne, L., Bodineau, G., Saby, N., Grolleau, E., 2002. A new initiative in France: a multi-institutional soil quality monitoring network. Comptes Rendus del'Académied'Agriculture de France 88, 93-105. 
1 Bert, V., Lors, C., Ponge, J.F., Caron, L., Biaz, A., Dazy, M., Masfaraud, J.F., 2012. Metal immobilization and soil amendment efficiency at a contaminated sediment landfill site: a field study focusing on plants, springtails, and bacteria. Environmental Pollution 169, 1-11.

Bispo, A., Cluzeau, D., Creamer, R., Dombos, M., Greafe, U., Krogh, P.H., Sousa, J.P., Pérès, G., Rutgers, M., Winding, A., Römbke, J., 2009.Indicators for monitoring soil biodiversity. Integrated Environmental Assessment and Management 5, 717-719.

Black, H.I.J., Parekh, N.R., Chaplow, J.S., Monson, F., Watkins, J., Creamer, R., Potter, E.D., Poskitt, J.M., Rowland, P., Ainsworth, G., Hornung, M., 2003. Assessing soil biodiversity across great Britain: national trends in the occurrence of heterotrophic bacteria and invertebrates in soil. Journal of Environmental Management 67, 255-266.

Block, W., 1966.Some characteristics of the Macfadyen high gradient extraction for soil microarthropods. Oikos 17, 1-9.

Blouin, M., Zuily-Fodil, Y., Pham-Thi, A.T., Laffray, D., Reversat, G., Pando, A., Tondoh, J., Lavelle, P., 2005. Belowground organism activities affect plant aboveground phenotype, inducing plant tolerance to parasites. Ecology Letters 8, 202-208.

Bongers, T., 1990. The maturity index: an ecological measure of environmental disturbance based on nematode species composition. Oecologia 83, 14-19.

Bongers, T., Bongers, M., 1998.Functional diversity of nematodes.Applied Soil Ecology 10, 239-251.

Bonkowski, M., Griffiths, B., Scrimgeour, C., 2000.Substrate heterogeneity and microfauna in soil organic 'hotspots' as determinants of nitrogen capture and growth of ryegrass.Applied Soil Ecology 14, 37-53.

Bouché, M.B., 1972. Lombriciens de France.Écologie et Systématique. Institut National de la Recherche Agronomique, Paris. 
1 Bruce, L.J., McCracken, D.I., Foster, G.N., Aitken, M.N., 1999. The effects of sewage sludge on grassland euedaphic and hemiedaphic collembolan populations. Pedobiologia 43, 209-220.

Burel, F., Baudry, J., Butet, A., Clergeau, P., Delettre, Y., Le Cœur, D., Dubs, F., Morvan, N., Paillat, G., Petit, S., Thenail, C., Brunel, E., Lefeuvre, J.C., 1998. Comparative biodiversity along a gradient of agricultural landscapes.ActaOecologica19, 47-60.

Carpenter, D., Hodson, M.E., Eggleton, P., Kirk, C., 2007. Earthworm induced mineral weathering: preliminary results. European Journal of Soil Biology 43, S176-S183.

Chaussod, R., Houot, S., Guiraud, G., Hétier J.M., 1988. Size and turnover of the microbial biomass in agricultural soils: laboratory and field measurements. In: Jenkinson, D.S., Smith, K.E. (Eds.), Nitrogen Efficiency in Agricultural Soils and the Efficient Use of Fertilizer Nitrogen. Elsevier Applied Science, London, pp. 312-326.

Chauvat, M., Wolters, V., Dauber, J., 2007.Response of collembolan communities to land-use change and grassland succession.Ecography 30, 183-192.

Chirinda, N., Carter, M.S., Albert, K.R., Ambus, P., Olesen, J.E., Porter, J.R., Petersen, S.O., 2010. Emissions of nitrous oxide from arable organic and conventional cropping systems on two soil types.Agriculture, Ecosystems andEnvironment 136, 199-208.

Cluzeau, D., Binet, F., Vertes, F., Simon, J.C., Rivière, J.M., Trehen, P., 1992. Effects of intensive cattle trampling on soil-plant-earthworms system in two grassland types.Soil Biology and Biochemistry 24, 1661-1665.

Cluzeau, D., Cannavacciulo, M., Pérès, G., 1999. Indicateurs macrobiologiques des sols: les lombriciens. Méthode d'échantillonnage dans les agrosystèmes en zone tempérée. In: Euroviti 99,Douzième Colloque Viticole et Enologique, Montpellier, France, November 16-18, 1999. Institut Technique de la Vigne, Paris, pp. 25-35.

Cluzeau, D., Guernion, M., Chaussod, R., Martin-Laurent, F., Villenave, C., Cortet, J., Ruiz-Camacho, N., Pernin, C., Mateille, T., Philippot, L., Bellido, A., Rougé, L., Arrouays, D., Bispo, A., 
Pérès, G., 2012. Integration of biodiversity in soil quality monitoring: baselines for microbial and soil fauna parameters for different land-use types. European Journal of Soil Biology 49, $63-72$.

Cluzeau, D., Lemercier, N., Ablain, F., Pérès, G., Grandin, V., 2003. Écologie des Lombriciens et Interactions avec les Activités Agricoles en Zone Tempérée (Cas Particulier du Cuivre). Les Cahiers du BIOGER 2/2003.

Cluzeau, D., Pérès, G., Guernion, M., Chaussod, R., Cortet, J., Fargette, M., Martin-laurent, F., Mateille, T., Pernin, C., Ponge, J.F., Ruiz-Camacho, N., Villenave, C., Rougé, L., Mercier, V., Bellido, A., Cannavacciuolo, M., Piron, D., Arrouays, D., Boulonne, L., Jolivet, C., Lavelle, P., Velasquez, E., Plantard, O., Walter, C., Foucaud-Lemercier, B., Tico, S., Giteau, J.L., Bispo, A., 2009. Intégration de la biodiversité des sols dans les réseaux de surveillance de la qualité des sols: exemple du programme-pilote à l'échelle régionale, le RMQS BioDiv. Étude et Gestion des Sols 16, 187-201.

Cole, L., Buckland, S.M., Bardgett, R.D., 2005. Relating microarthropod community structure and diversity to soil fertility manipulations in temperate grassland. Soil Biology and Biochemistry37, 1707-1717.

Cortet, J., Gillon, D., Joffre, R., Ourcival, J.M., Poinsot-Balaguer, N., 2002a. Effects of pesticides on organic matter recycling and microarthropods in a maize field : use and discussion of the litterbag methodology. European Journal of Soil Biology 38, 261-265.

Cortet, J., Ronce, D., Poinsot-Balaguer, N., Beaufreton, C., Chabert, A., Viaux, P., Cancela da Fonseca, J.P., 2002b. Impacts of different agricultural practices on the biodiversity of microarthropod communities in arable crop systems.European Journal of Soil Biology 38, $239-244$

Cox, D., Bezdicek, D., Fauci, M., 2001. Effects of compost, coal ash, and straw amendments on restoring the quality of eroded Palouse soil.Biology and Fertility of Soils 33, 365-372. 
1 Debeljak, M., Cortet, J., Demšar, D., Krogh, P.H., Džeroski, S., 2007. Hierarchical classification of environmental factors and agricultural practices affecting soil fauna under cropping systems using Bt maize. Pedobiologia 51, 229-238.

Decaëns, T., 2010.Macroecological patterns in soil communities. Global Ecology and Biogeography $19,287-302$.

Decaëns, T., Margerie, P., Aubert, M., Hedde, M., Bureau, F., 2008. Assembly rules within earthworm communities in north-western France: a regional analysis. AppliedSoil Ecology 39, 321-335.

De Deyn, G.B., Raaijmakers, C.E., Zoomer, H.R., Berg, M.P., De Ruiter, P.C., Verhoef, H.A., Bezemer, T.M., Van der Putten, W.H., 2003. Soil invertebrate fauna enhances grassland succession and diversity. Nature 422, 711-713.

De Goede, R.G.M., Brussaard, L., Akkermans, A.D.L., 2003. On-farm impact of cattle slurry manure management on biological soil quality. NJASWageningen Journal of Life Sciences 51, 103133.

Dirzo, R., Domínguez, C.A., 1995.Plant-herbivore interactionsin Mesoamerican tropical dry forests. In: Bullock, S.H., Mooney, H.A., Medina, E. (Eds.), Seasonal Dry Tropical Forests. Cambridge University Press, Cambridge, pp. 304-325.

Dombos, M., 2001. Collembola of loess grassland: effects of grazing and landscape on community composition. Soil Biology and Biochemistry 33, 2037-2045.

Duffield, S.J., Aebischer, N.J., 1994.The effect of spatial scale of treatment with dimethoate on invertebrate population recovery in winter wheat. Journal of Applied Ecology 31, 263-281.

Duxbury, J.M., Smith, M.S., Doran, J.W., Jordan, C., Szott, L., Vance, E., 1989. Soil organic matter as a source and a sink of plant nutrients. In: Coleman, D.C., Oades, J.M., Uehara, G. (Eds.), Dynamics of Soil Organic Matter in Tropical Ecosystems. University of Hawaii Press, Honolulu, pp. 33-67. 
1 EC, 2006.Proposal for a Directive of the European Parliament and of the Council establishing a framework for the protection of soil and amending Directive 2004/35/EC.Commission of the European Communities, Brussels.

Edwards, C.A., Lofty, J.R., 1975. The influence of cultivations on soil animal populations. In: Vanek, J. (Ed.), Progress in Soil Zoology. Academia, Prague, pp. 399-407.

Eggleton, P., Vanbergen, A.J., Jones, D.T., Lambert, M.C., Rockett, C., Hammond, P.M., Beccaloni, J., Marriott, D., Ross, E., Giusti, A., 2005. Assemblages of soil macrofauna across a Scottish land-use intensification gradient: influences of habitat quality, heterogeneity and area. Journalof Applied Ecology 42, 1153-1164.

Eijsackers, H., 2011. Earthworms as colonizers of natural and cultivated soil environments.Applied Soil Ecology 50, 1-13.

Eisenhauer, N., 2010. The action of an animal ecosystem engineer: identification of the main mechanisms of earthworm impacts on soil microarthropods. Pedobiologia 53, 343-352.

Eisenhauer, N., Hörsch, V., Moeser, J., Scheu, S., 2010.Synergistic effects of microbial and animal decomposers on plant and herbivore performance. Basic and Applied Ecology 11, 23-34.

Endlweber, K., Krome, K., Welzl, G., Schäffner, A.R., Scheu, S., 2011. Decomposer animals induce differential expression of defence and auxin-responsive genes in plants. Soil Biology and Biochemistry 43, 1130-1138.

Ettema, C.H., Bongers, T., 1993. Characterization of nematode colonization and succession in disturbed soil using the Maturity Index.Biology and Fertility of Soils 16, 79-85.

Ferris, H., Bongers, T., De Goede, R.G.M., 2001. A framework forsoil web diagnostics: extension of the nematode faunalanalysis concept. Applied Soil Ecology 18, 13-29. 
1 Fierer, N., Jackson, R.B., 2006. The diversity and biogeography of soil bacterial communities.Proceedings of the National Academy of Sciences of the United States of America 103, 626-631.

Filser, J., 1995.The effect of green manure on the distribution of Collembola in a permanent row crop. Biology and Fertility of Soils 19, 303-308.

Filser, J., Mebes, K.H., Winter, K., Lang, A., Kampichler, C., 2002. Long-term dynamics and interrelationships of soil Collembola and microorganisms in an arable landscape following land use change. Geoderma 105, 201-221.

Fließbach, A., Oberholzer, H.R., Gunst, L., Mäder, P., 2007. Soil organic matter and biological soil quality indicators after 21 years of organic and conventional farming.Agriculture, Ecosystems andEnvironment 118, 273-284.

Forey, E., Barot, S., Decaëns, T., Langlois, E., Laossi, K.R., Margerie, P., Scheu, S., Eisenhauer, N., 2011. Importance of earthworm-seed interactions for the composition and structure of plant communities: a review. ActaOecologica 37, 594-603.

Frampton, G.K., 1997. The potential of Collembola as indicators of pesticide usage: evidence and methods from the UK arable ecosystem. Pedobiologia 41, 179-184.

Frampton, G.K., Van den Brink, P.J., Wratten, S.D., 2001. Diel activity patterns in an arable collembolan community. Applied Soil Ecology 17, 63-80.

Freckman, D.W., 1988. Bacterivorous nematodes and organic matter decomposition. Agriculture, Ecosystems and Environment 24, 195-217.

Guttiérrez-López, M., Salmon, S., Trigo, D., 2011. Movement response of Collembola to the excreta of two earthworm species: importance of ammonium content and nitrogen forms. Soil Biology and Biochemistry 43, 55-62. 
1 Hamilton, W.E., Sillman, D.Y., 1989. Influence of earthworm middens on the distribution of soil microarthropods. Biology and Fertility of Soils 8, 279-284.

Harden, T., Joergensen, R.G., Meyer, B., Wolters, V., 1993. Soil microbial biomass estimated by fumigation-extraction and substrate-induced respiration in two pesticide-treated soils. Soil Biology and Biochemistry 25, 679-683.

Harris, J.A., 2003. Measurements of the soil microbial community for estimating the success of restoration. European Journal of Soil Science 54, 801-808.

Hedde, M., Van Oort, F., Lamy, I., 2012.Functional traits of soil invertebrates as indicators for exposure to soil disturbance.Environmental Pollution 164, 59-65.

Hedlund, K., Griffiths, B., Christensen, S., Scheu, S., Setälä, H., Tscharntke, T., Verhoef, H., 2004. Trophic interactions in changing landscapes: responses of soil food webs. Basic and Applied Ecology 5, 495-503.

Heil, M., 2011.Plant-mediated interactions between above- and below-ground communities at multiple trophic levels. Journal of Ecology 99, 3-6.

Heisler, C., Kaiser, E.A., 1995. Influence of agricultural traffic and crop management on Collembola and microbial biomass in arable soil. Biology and Fertility of Soils 19, 159-165.

Hyvönen, R., Andersson, S., Clarholm, M., Persson, T., 1994. Effect of lumbricids and enchytraeids on nematodes in limed and unlimed coniferous mor humus. Biology and Fertility of Soils 17, 201-205.

Ingham, R.E., Trofymow, J.A., Ingham, E.R., Coleman, D.C., 1985.Interactions of bacteria, fungi and their nematode grazers: effects on nutrient cycling and plant growth. Ecological Monographs $55,119-140$.

Insam, H., Domsch, K.H., 1988. Relationship between soil organic carbon and microbial biomass on chronosequences of reclamation sites. Microbial Ecology 15, 177-188. 
1 ISO, 1997.ISO 14240-2.Soil quality.Determination of Soil Microbial Biomass.Part 2.FumigationExtraction Method.International Organization for Standardization, Geneva.

ISO, 2006.ISO 23611-2.Soil quality.Sampling of Soil Invertebrates.Part 2.Sampling and Extraction of Micro-Arthropods (Collembola and Acarina).International Organization for Standardization, Geneva.

ISO, 2007.ISO 23611-4.Soil Quality.Sampling of Soil Invertebrates.Part 4.Sampling, Extraction and Identification of Soil-Inhabiting Nematodes.International Organization for Standardization, Geneva.

ISO, 2011.ISO 23611-5.Soil Quality.Sampling of Soil Invertebrates.Part 5.Sampling and Extraction of Soil Macro-Invertebrates.International Organization for Standardization, Geneva.

ISO, 2012.ISO 11063.Soil quality.Method to Directly Extract DNA from Soil Samples.International Organization for Standardization, Geneva.

Jangid, K., Williams, M.A., Franzluebbers, A.J., Schmidt, T.M., Coleman, D.C., Whitman, W.B., 2011. Land-use history has a stronger impact on soil microbial community composition than aboveground vegetation and soil properties. Soil Biology and Biochemistry 43, 2184-2193.

Jégou, D., Schrader, S., Diestel, H., Cluzeau, D., 2001. Morphological, physical and biochemical characteristics of burrow walls formes by earthworms.Applied Soil Ecology 17, 165-174.

Jensen, L.S., Pedersen, I.S., Hansen, T.B., Nielsen, N.E., 2000. Turnover and fate of ${ }^{15} \mathrm{~N}$-labelled cattle slurry ammonium- $\mathrm{N}$ applied in the autumn to winter wheat. EuropeanJouranl of Agronomy 12, 23-35.

Jolivet, C., Arrouays, D., Boulonne, L., Ratié, C., Saby, N., 2006a. Le Réseau de Mesures de la Qualité des Sols de France (RMQS): état d'avancement et premiers résultats. Étude et Gestion des Sols 13, 149-164. 
1 Jolivet, C., Boulonne, L., Ratié, C., 2006b. Manuel du Réseau de Mesures de la Qualité des Sols de France (RMQS). INRA, Orléans.

Jouquet, P., Dauber, J., Lagerlöf, J., Lavelle, P., Lepage, M., 2006. Soil invertebrates as ecosystem engineers: intended and accidental effects on soil and feedback loops. Applied Soil Ecology $32,153-164$.

Kardol, P., Bezemer, T.M., Van der Wal, A., Van der Putten, W.H., 2005. Sucessional trajectories of soil nematode and plant communities in a chronosequences of ex-arable land. Biological Conservation 126, 317-327.

Keith, A.M., Boots, B., Hazard, C., Niechoj, R., Arroyo, J., Bending, G.D., Bolger, T., Breen, J., Clipson, N., Doohan, F.M., Griffin, C.T., Schmidt, O., 2012.Cross-taxa congruence, indicators and environmental gradients in soils under agricultural and extensive land management. European Journal of Soil Biology 49, 55-62.

Kováč, L., 1994. Effects of soil type on collembolan communities in agroecosystems. ActaZoologicaFennica 195, 89-93.

Krogh, P.H., Griffiths, B., Demšar, D., Bohanec, M., Debeljak, M., Andersen, M.N., Sausse, C., Birch, A.N.E., Caul, S., Holmstrup, M., Heckmann, L.H., Cortet, J., 2007. Responses by earthworms to reduced tillage in herbicide tolerant maize and $B t$ maize cropping systems. Pedobiologia 51, $219-227$.

Lagomarsino, A., Grego, S., Marhan, S., Moscatelli, M.C., Kandeler, E., 2009. Soil management modifies micro-scale abundance and function of soil microorganisms in a Mediterranean ecosystem. European Journal of Soil Science 60, 2-12.

Lamandé, M., Hallaire, V., Curmi, P., Pérès, G., Cluzeau, D., 2003. Changes of pore morphology, infiltration and earthworm community in a loamy soil under different agricultural managements.Catena 54, 637-649. 
1 Lavelle, P., 1988. Assessing the abundance and role of invertebrate communities in tropical soils: aims and methods.Journal of African Zoology 102, 275-283.

Lavelle, P., Decaëns, T., Aubert, M., Barot, S., Blouin, M., Bureau, F., Margerie, P., Mora, P., Rossi, J.P., 2006. Soil invertebrates and ecosystem services.European Journal of Soil Biology 42, S3-S15.

Loranger, G., Ponge, J.F., Blanchart, E., Lavelle, P., 1998. Impact of earthworms on the diversity of microarthropods in a vertisol (Martinique).Biology and Fertility of Soils 27, 21-26.

Loranger-Merciris, G., Barthes, L., Gastine, A., Leadley, P., 2006.Rapid effects of plant species diversity and identity on soil microbial communities in experimental grassland ecosystems. Soil Biology and Biochemistry 38, 2336-2343.

Maraun, M., Alphei, J., Bonkowski, M., Buryn, R., Migge, S., Peter, M., Schaefer, M., Scheu, S., 1999. Middens of the earthworm Lumbricus terrestris (Lumbricidae): microhabitats for microand mesofauna in forest soil. Pedobiologia 43, 276-287.

Marinissen, J.C.Y., Bok, J., 1988. Earthworm-amended soil structure: its influence on Collembola populations in grassland. Pedobiologia 32, 243-252.

Martin-Laurent, F., Philippot, L., Hallet, S., Chaussod, R., Germon, G., Soulas, G., Catroux G., 2001. DNA extraction from soils: old bias for new microbial diversity analysis methods. Applied and Environmental Microbiology 67, 2354-2359.

Mebes, K.H., Filser, J., 1997. A method for estimating the significance of surface dispersal for population fluctuations of Collembola in arable land.Pedobiologia 41, 115-122.

Mitschunas, N., Wagner, M., Filser, J., 2006.Evidence for a positive influence of fungivorous soil invertebrates on the seed bank persistence of grassland species. Journal of Ecology 94, 791800. 
1 Monroy, F., Aira, M., Domínguez, J., 2008. Changes in density of nematodes, protozoa and total coliforms after transit through the gut of four epigeic earthworms (Oligochaeta).Applied Soil Ecology 39, 127-132.

Monroy, F., Aira, M., Domínguez, J., 2011.Epigeic earthworms increase soil arthropod populations during first steps of decomposition of organic matter. Pedobiologia 54, 93-99.

Murray, P.J., Clegg, C.D., Crotty, F.V., de la Fuente Martinez, N., Williams, J.K., Blackshaw, R.P., 2009. Dissipation of bacterially derived $\mathrm{C}$ and $\mathrm{N}$ through the meso- and macrofauna of a grassland soil. Soil Biology and Biochemistry 41, 1146-1150.

Nair, A., Ngouajio, M., 2012. Soil microbial biomass, functional microbial diversity, and nematode community structure as affected by cover crops and compost in an organic vegetable production system. Applied Soil Ecology 58, 45-55.

Osler, G.H.R., Murphy, D.V., 2005. Oribatid mite species richness and soil organic matter fractions in agricultural and native vegetation soils in Western Australia. Applied Soil Ecology 29, 93-98.

Parisi, V., Menta, C., Gardi, C., Jacomini, C., Mozzanica, E., 2005.Microarthropod communities as a tool to assess soil quality and biodiversity: a new approach in Italy. Agriculture, Ecosystems and Environment 105, 323-333.

Pelosi, C., Bertrand, M., Roger-Estrade, J., 2009. Earthworm community in conventional, organic and direct seeding with living mulch cropping systems.Agronomy forSustainable Development 29, 287-295.

Petersen, H., Jucevica, E., Gjelstrup, P., 2004. Long-term changes in collembolan communities in grazed and non-grazed abandoned arable fields in Denmark.Pedobiologia 48, 559-573.

Petric, I., Philippot, L., Abbate, C., Bispo, A., Chesnot, T., Hallin, S., Laval, K., Lebeau, T., Lemanceau, P., Leyval, C., Lindström, K., Pandard, P., Romero, E., Sarr, A., Schloter, M., Simonet, P., Smalla, K., Wilke, B.M., Martin-Laurent, F., 2011.Inter-laboratory evaluation of 
the ISO standard 11063 "Soil quality - Method to directly extract DNA from soil saples. Journal of Microbiological Methods 84, 454-460.

Pižl, V., 1992.Effect of soil compaction on earthworms (Lumbricidae) in apple orchard soil. Soil Biology and Biochemistry 24, 1573-1575.

Ponge, J.F., 2013. Plant-soil feebacks mediated by humus forms: a review. Soil Biology and Biochemistry 57, 1048-1060.

Ponge, J.F., Chevalier, R., 2006. Humus Index as an indicator of foreststand and soil properties. Forest Ecology and Management 233, 165-175.

Ponge, J.F., Chevalier, R., Loussot, P., 2002. Humus Index: an integrated tool for the assessment of forest floor and topsoil properties. Soil Science Society of America Journal 66, 1996-2001.

Ponge, J.F., Dubs, F., Gillet, S., Sousa, J.P., Lavelle, P., 2006. Decreased biodiversity in soil springtail communities: the importance of dispersal and landuse history in heterogeneous landscapes. Soil Biology and Biochemistry 38, 1158-1161.

Ponsard, S. Arditi, R., Jost, C., 2000. Assessing top-down and bottom-up control in a litter-based soil macroinvertebrate food chain.Oikos 89, 529-540.

Popovici, I., Ciobanu, M., 2000.Diversity and distribution of nematode communities in grasslands from Romania in relation to vegetation and soil characteristics.Applied Soil Ecology 14, 27 36.

Postma-Blaauw, M.B., De Goede, R.G.M., Bloem, J., Faber, J.H., Brussaard, L., 2010.Soil biota community structure and abundance under agricultural intensification and extensification. Ecology 91, 460-473.

Postma-Blaauw, M.B., De Goede, R.G.M., Bloem, J., Faber, J.H., Brussaard, L., 2012. Agricultural intensification and de-intensification differentially affect taxonomic diversity of predatory mites, earthworms, enchytraeids, nematodes and bacteria. Applied Soil Ecology 57, 39-49. 
1 Ranjard, L., Dequiedt, S., Jolivet, C., Saby, N.P.A., Thioulouse, J., Harmand, J., Loisel, P., Rapaport, A., Fall, S., Simonet, P., Joffre, R., Boure, N.C.P., Maron, P.A.,Mougel, C.,Martin, M.P., Toutain, B., Arrouays, D.,Lemanceau, P., 2010. Biogeography of soil microbial communities: a review and a description of the ongoing French national initiative. Agronomy for Sustainable Development 30, 359-365.

Rebecchi, L., Sabatini, M.A., Cappi, C., Grazioso, P., Vicari, A., Dinelli, G., Bertolani, R., 2000. Effects of a sulfonylurea herbicide on soil microarthropods. Biology andFertility ofSoils 30, $312-317$.

Rutgers, M., Schouten, A.J., Bloem, J., Van Eekeren, N., De Goede, R.G.M., Jagers op Akkerhuis, G.A.J.M., Van der Wal, A., Mulder, C., Brussaard, L., Breure, A.M., 2009. Biological measurements in a nationwide soil monitoring network. European Journal of Soil Science 60, $820-832$.

Saby, N.P.A., Marchant, B.P., Lark, R.M., Jolivet, C.C., Arrouays, D., 2011. Robust geostatistical prediction of trace elements across France.Geoderma 162, 303-311.

Salmon, S., 2004. The impact of earthworms on the abundance of Collembola: improvement of food resources or of habitat? Biology and Fertility of Soils 40, 323-333.

Sanon, A., Andrianjaka, Z.N., Prin, Y., Bally, R., Thioulouse, J., Comte, G., Duponnois, R., 2009.Rhizosphere microbiotainterfers with plant-plant interactions. Plant and Soil 321, 259278.

Sasada, Y., Win, K.T., Nonaka, R., Win, A.T., Toyota, K., Motobayashi, T., Hosomi, M., Dingjiang, C., Lu, J., 2011. Methane and $\mathrm{N}_{2} \mathrm{O}$ emissions, nitrate concentrations of drainage water, and zinc and copper uptake by rice fertilized with anaerobically digested cattle or pig slurry. Biology and Fertility of Soils 47, 949-956. 
1 Satchell, J.E., 1980. $\mathrm{r}$ worms and K worms: a basis for classifying lumbricid earthworm strategies. In: Dindal, D.L. (Ed.), Soil Biology as Related to Land Use Practices. Environmental Protection Agency, Washington, D.C., pp. 848-864.

Sattler, C., Kächele, H., Verch, G., 2007. Assessing the intensity of pesticide use in agriculture. Agriculture, Ecosystems and Environment 119, 299-304.

Stoate, C., Boatman, N.D., Borralho, R.J., Rio Carvalho, C., De Snoo, G.R., Eden, P., 2001. Ecological impacts of arable intensification in Europe. Journal of Environmental Management $63,337-365$.

Tiunov, A.V., Scheu, S., 2004. Carbon availability controls the growth of detritivores (Lumbricidae) and their effects on nitrogen mineralization. Oecologia 138, 83-90.

Topoliantz, S., Ponge, J.F., Viaux, P., 2000. Earthworm and enchytraeid activity under different arable farming systems, as exemplified by biogenic structures.Plant and Soil 225, 39-51.

Van der Heijden, M.G.A., Bardgett, R.D., Van Straalen, N.M., 2008. The unseen majority: soil microbes as drivers of plant diversity and productivity in terrestrial ecosystems. Ecology Letters 11, 296-310.

Van der Wal, A., Geerts, R.H.E.M., Korevaar, H., Schouten, A.J., Jagers op Akkerhuis, G.A.J.M., Rutgers, M., Mulder, C., 2009.Dissimilar response of plant and soil biota communities to long-term nutrient addition in grasslands. Biology and Fertility of Soils 45, 663-667.

Van Eekeren, N., De Boer, H., Bloem, J., Schouten, T., Rutgers, M., De Goede, R., Brussaard, L., 2009. Soil biological quality of grassland fertilized with adjusted cattle manure slurries in comparison with organic and inorganic fertilizers. Biology and Fertility of Soils 45, 595-608.

Velasquez, E., Lavelle, P., Andrade, M., 2007. GISQ, a multifunctional indicator of soil quality.Soil Biology and Biochemistry 39, 3066-3080. 
1 Villenave, C., Jimenez, A., Guernion, M., Pérès, G., Cluzeau, D., Mateille, T., Martiny, B., Fargette, M., Tavoillot, J., 2013. Nematodes for soil quality monitoring: results from the RMQS BioDiv programme. Open Journal of Soil Science 3, 30-45.

Winkler, H., Kamplicher, C., 2000. Local and regional species richness in communities of surfacedwelling grassland Collembola: indication of species saturation. Ecography 23, 385-392.

Wolters, V., 2000.Invertebrate control of soil organic matter stability. Biology and Fertility of Soils $31,1-19$.

Wright, M.A., 1977. Effects of benomyl and some other systemic fungicides on earthworms. Annals of Applied Ecology 87, 520-524.

Wyss, E., Glasstetter, M., 1992.Tillage treatments and earthworm distribution in a Swiss experimental corn field. Soil Biology and Biochemistry 24, 1635-1639.

Yan, S.K., Singh, A.N., Fu, S.L., Liao, C.H., Wang, S., Li, Y.L., Cui, Y., Hu, L., 2012. A soil fauna index for assessing soil quality. Soil Biology and Biochemistry 47, 158-165.

Yeates, G.W., 2003. Nematodes as soil indicators: functional and biodiversity aspects. Biology and Fertility of Soils 37, 199-210.

Yeates, G.W., Bird, A.F., 1994. Some observations on the influence of agricultural practices on the nematode faunae of some South Australian soils.Fundamental and Applied Nematology 17, $133-145$.

Zajonc, I., 1975. Variations in meadow associations of earthworms caused by the influence of nitrogen fertilizers and liquid-manure irrigation. In: Vanek, J. (Ed.), Progress in Soil Zoology. Academia, Prague, pp. 497-503.

Zan, C.S., Fyles, J.W., Girouard, P., Samson, R.A., 2001. Carbon sequestration in perennial bioenergy, annual corn and uncultivated systems in southern Quebec.Agriculture, Ecosystems and Environment 86, 135-144. 
Table 1. Mean values of selected indicator variables according to land use (meadows and crop fields, permanent or in rotation) and slurry application (in permanent crop fields), and bulk comparisons by rank scores (see text). Confidence levels are indicated for Kruskal-Wallis test (for land use) and Mann-Whitney tests (for slurry application): $\mathrm{NS}=$ not significant; ${ }^{*}=\mathrm{P}<0.05 ;{ }^{* *}=\mathrm{P}<0.01 ;{ }^{* * *}=\mathrm{P}<0.001 ;{ }^{* * *}=\mathrm{P}<0.0001$. Upperscript letters indicate significant differences among means.

\begin{tabular}{|c|c|c|c|c|c|c|c|c|}
\hline & $\begin{array}{l}\text { Permanent } \\
\text { meadow }\end{array}$ & $\begin{array}{l}\text { Meadow in } \\
\text { rotation }\end{array}$ & $\begin{array}{l}\text { Crop in } \\
\text { rotation }\end{array}$ & $\begin{array}{l}\text { Permanent } \\
\text { crop }\end{array}$ & & Slurry & No slurry & \\
\hline Anecic earthworms (ind. $\mathrm{m}^{-2}$ ) & $64.5 \pm 13.5^{\mathrm{a}}$ & $58.4 \pm 12.2^{\mathrm{ab}}$ & $22.0 \pm 6.6^{\mathrm{b}}$ & $28.3 \pm 4.4^{\mathrm{b}}$ & $\star \star \star$ & $41.2 \pm 8.7$ & $25.3 \pm 4.6$ & NS \\
\hline Endogeic earthworms (ind. $\mathrm{m}^{-2}$ ) & $229 \pm 58$ & $211 \pm 28$ & $134 \pm 25$ & $167 \pm 23$ & NS & $230 \pm 42^{\mathrm{a}}$ & $124 \pm 16^{b}$ & ** \\
\hline Total macroacroarthropods and mollusks (ind. $\mathrm{m}^{-2}$ ) & $349 \pm 51^{\mathrm{a}}$ & $312 \pm 66^{\mathrm{ab}}$ & $130 \pm 20^{\mathrm{b}}$ & $173 \pm 22^{b}$ & 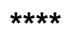 & $232 \pm 45^{\mathrm{a}}$ & $137 \pm 19^{b}$ & * \\
\hline Saprophagous macroarthropods and mollusks (ind. $\mathrm{m}^{-2}$ ) & $69.6 \pm 22.7^{\mathrm{a}}$ & $67.4 \pm 17.4^{\mathrm{ab}}$ & $23.8 \pm 7.6^{\mathrm{b}}$ & $24.6 \pm 6.7^{b}$ & $\star \star \star$ & $40.5 \pm 13.6^{\mathrm{a}}$ & $15.7 \pm 3.5^{\mathrm{b}}$ & * \\
\hline Epigeic springtails (ind. $\mathrm{m}^{-2}$ ) & $810 \pm 240^{b}$ & $3520 \pm 1130^{a b}$ & $5540 \pm 2370^{\mathrm{a}}$ & $4100 \pm 890^{\mathrm{a}}$ & * & $2480 \pm 800$ & $5150 \pm 1340$ & NS \\
\hline Phytoparasitic nematodes (ind. $\mathrm{g}^{-1}$ dry soil) & $1560 \pm 240^{\mathrm{a}}$ & $1050 \pm 200^{\mathrm{a}}$ & $620 \pm 90^{\mathrm{ab}}$ & $490 \pm 60^{b}$ & $\star \star \star$ & $470 \pm 90$ & $500 \pm 80$ & NS \\
\hline Bacterivorous nematodes (ind. $g^{-1}$ dry soil) & $574 \pm 88$ & $621 \pm 82$ & $687 \pm 155$ & $588 \pm 52$ & NS & $669 \pm 70^{\mathrm{a}}$ & $578 \pm 69^{b}$ & * \\
\hline Microbial biomass (mg C. $\mathrm{kg}^{-1}$ ) & $553 \pm 45^{\mathrm{a}}$ & $385 \pm 27^{\mathrm{ab}}$ & $269 \pm 29^{b c}$ & $243 \pm 11^{c}$ & 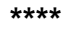 & $369 \pm 75$ & $460 \pm 72$ & NS \\
\hline Rank score & 1.8 & 2.1 & 3.0 & 3.1 & & 1.4 & 1.6 & \\
\hline
\end{tabular}


Table 2. Covariation between the 5 subsets of the biological database. Pearson correlation coefficients between first canonical factors of partial RDAs (second canonical factor for microarthropods). All coefficients significant at $P<0.0001$.

Earthworms Macrofauna Microarthropods Nematodes

\begin{tabular}{lllll}
\hline Macrofauna & 0.58 & & & \\
Microarthropods & -0.76 & -0.41 & & \\
Nematodes & 0.83 & 0.71 & -0.73 & \\
Microbes & 0.86 & 0.83 & -0.63 & 0.83 \\
\hline
\end{tabular}

2 
Table 3. Covariation between 3 subsets of the biological database. Pearson correlation coefficients between second canonical factors of partial RDAs. Significance levels: ${ }^{*},{ }^{* * *},{ }^{* * *}=\mathrm{P}<0.05,0.001,0.0001$, respectively.

\section{Earthworms Macrofauna}

Macrofauna $0.21^{*}$

Nematodes $0.37^{\star * \star}$

$0.47^{* \star * *}$

2 


\section{Figure Captions}

2 Fig. 1. Partial redundancy analysis (partial RDA), with earthworm data (listed in Appendix 2) as

3

4

7 Fig. 2.As Fig. 1 for macrofauna (macroarthropods and mollusks).

8 Fig. 3.As Fig. 1 for microarthropods.

$9 \quad$ Fig. 4.As Fig. 1 for nematodes.

10

Fig. 5.As Fig. 1 for microbial data. 


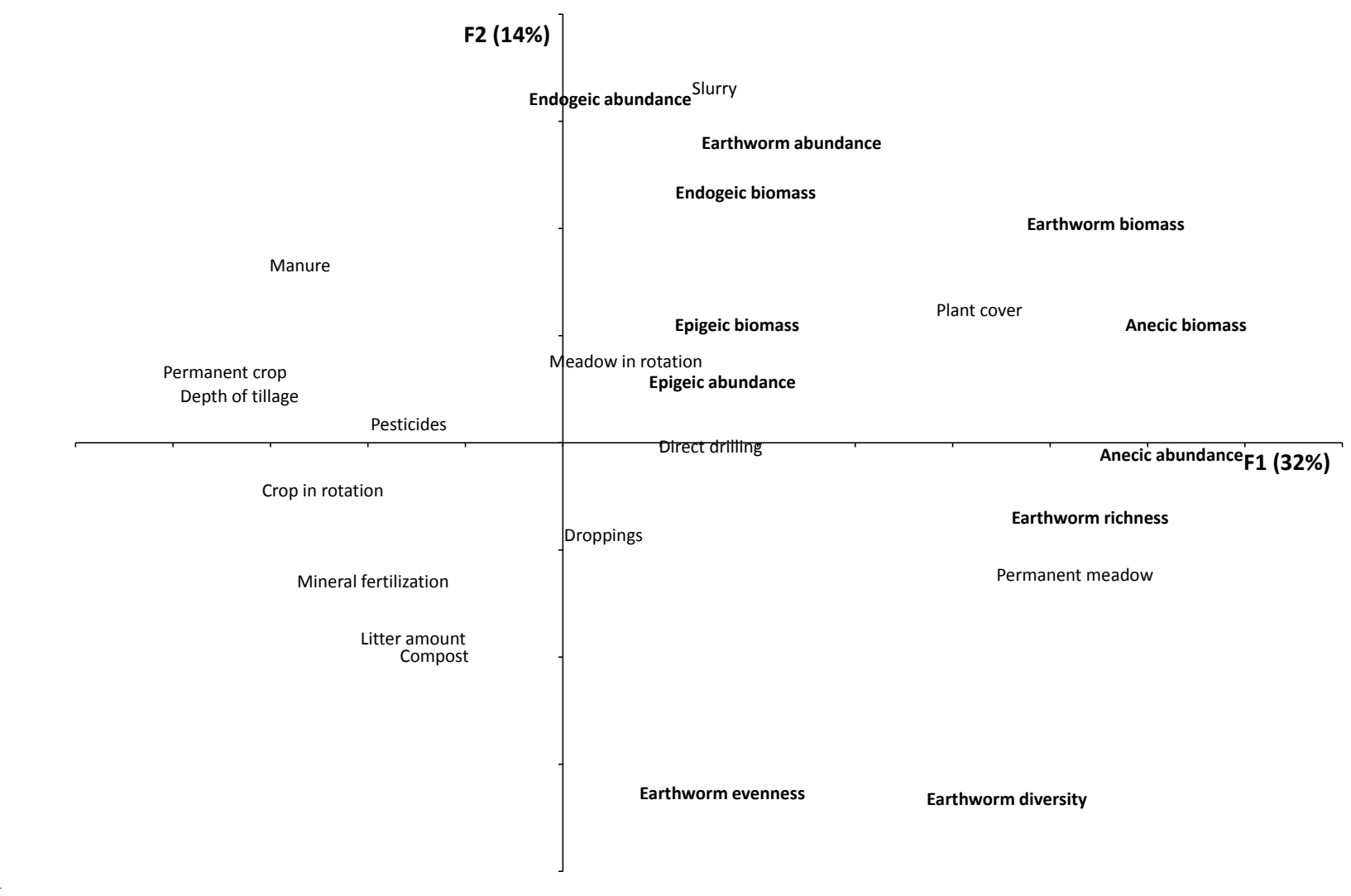

2 Fig. 1 


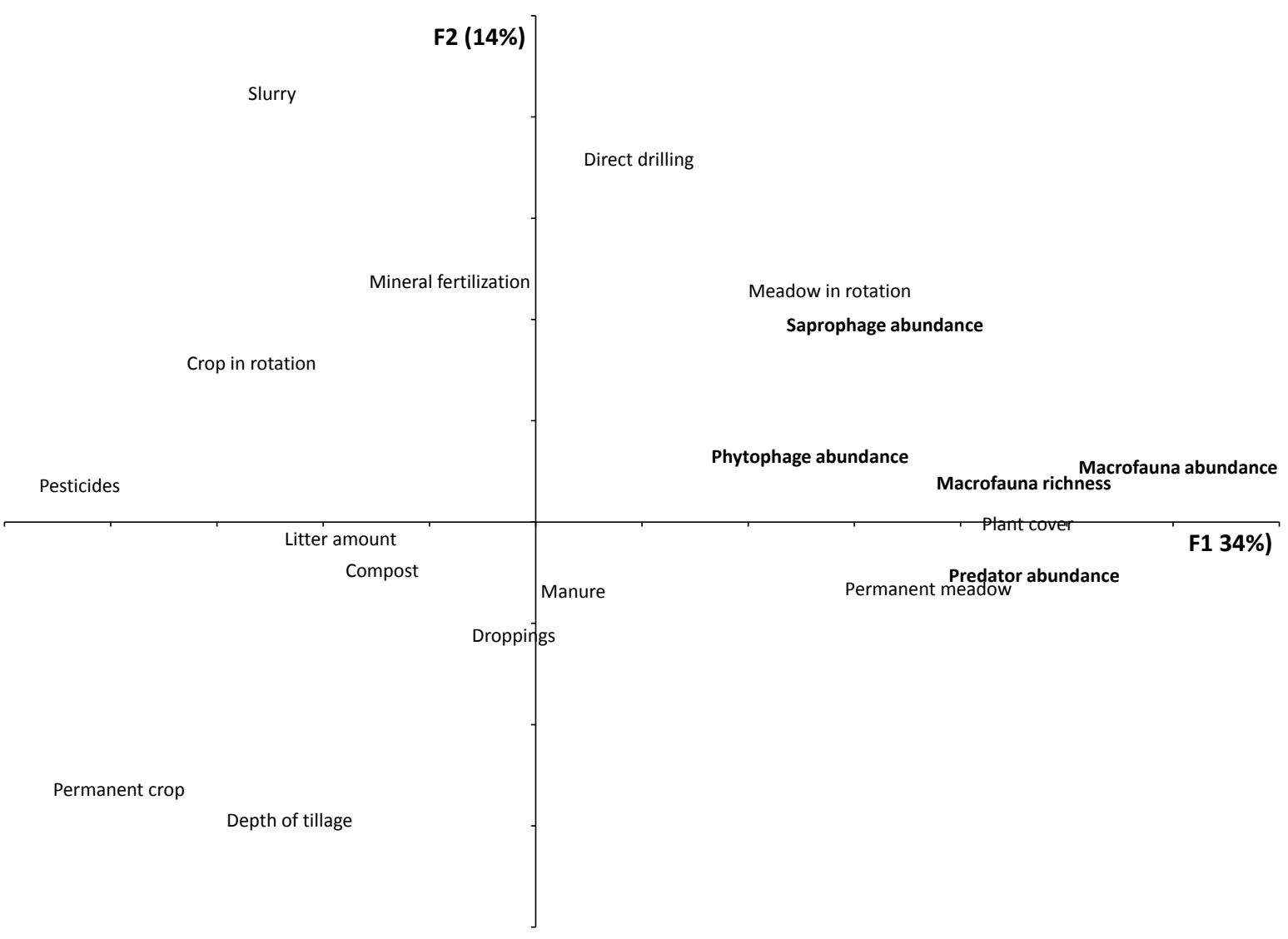

Fig. 2 


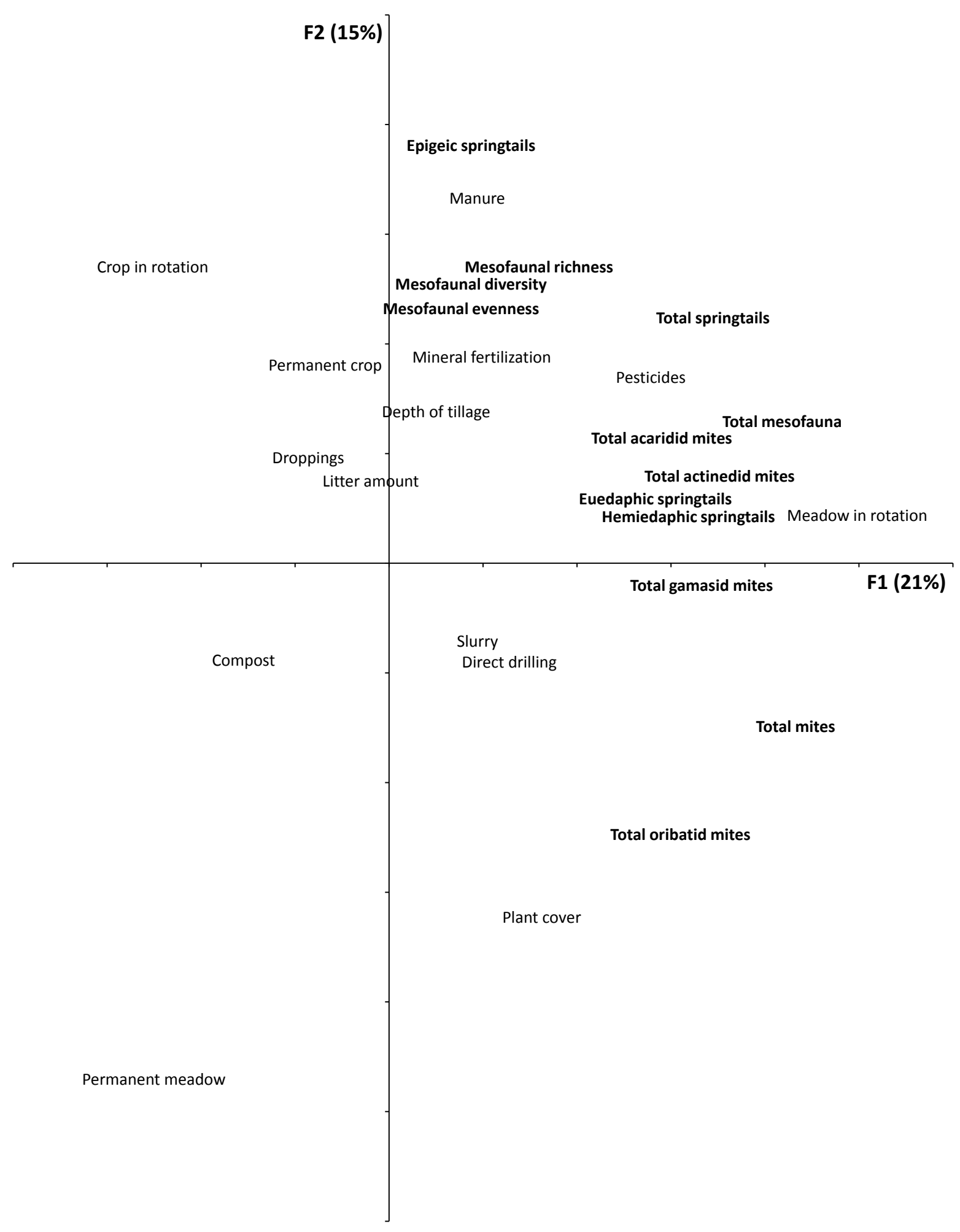

2 Fig. 3 


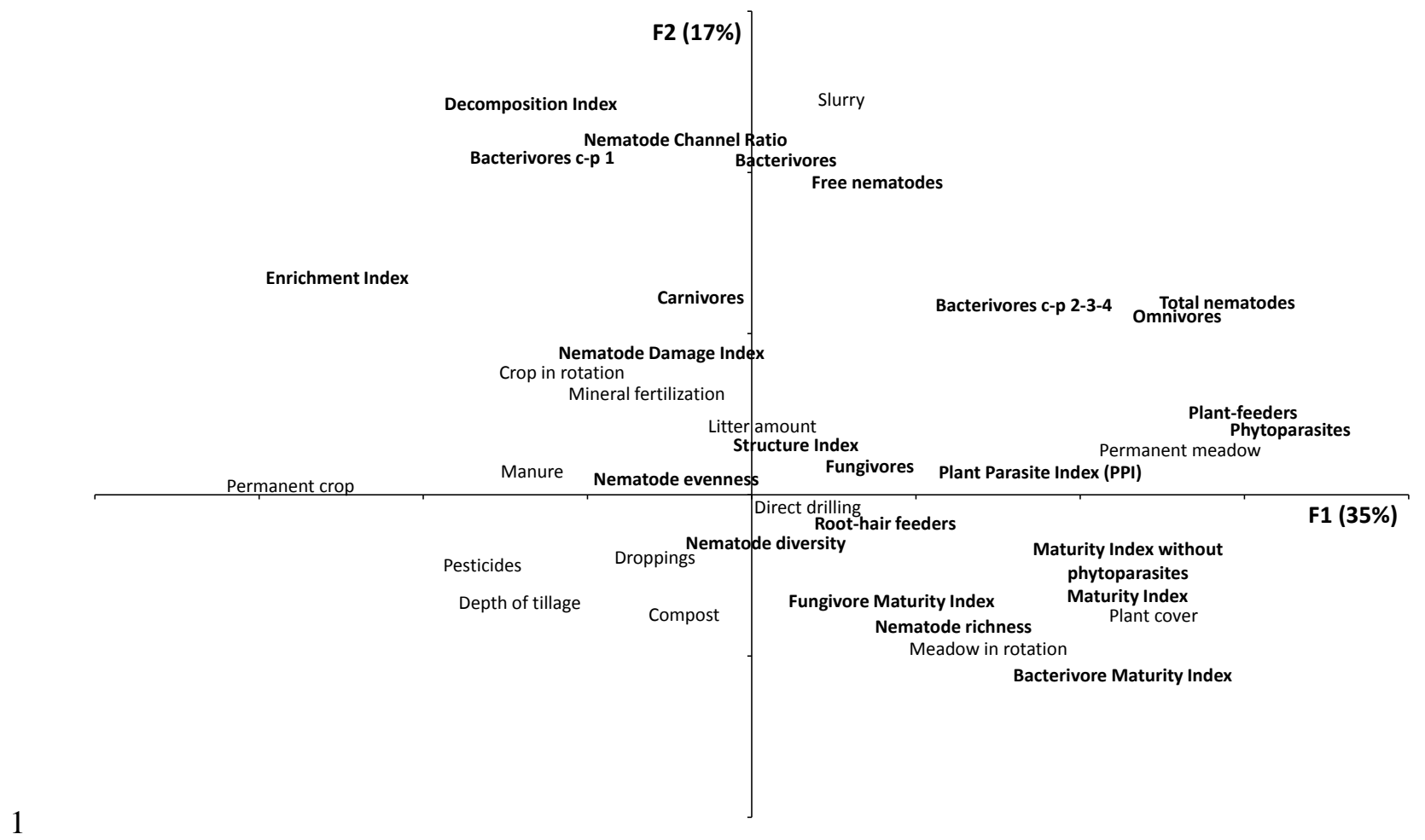

$2 \quad$ Fig. 4 


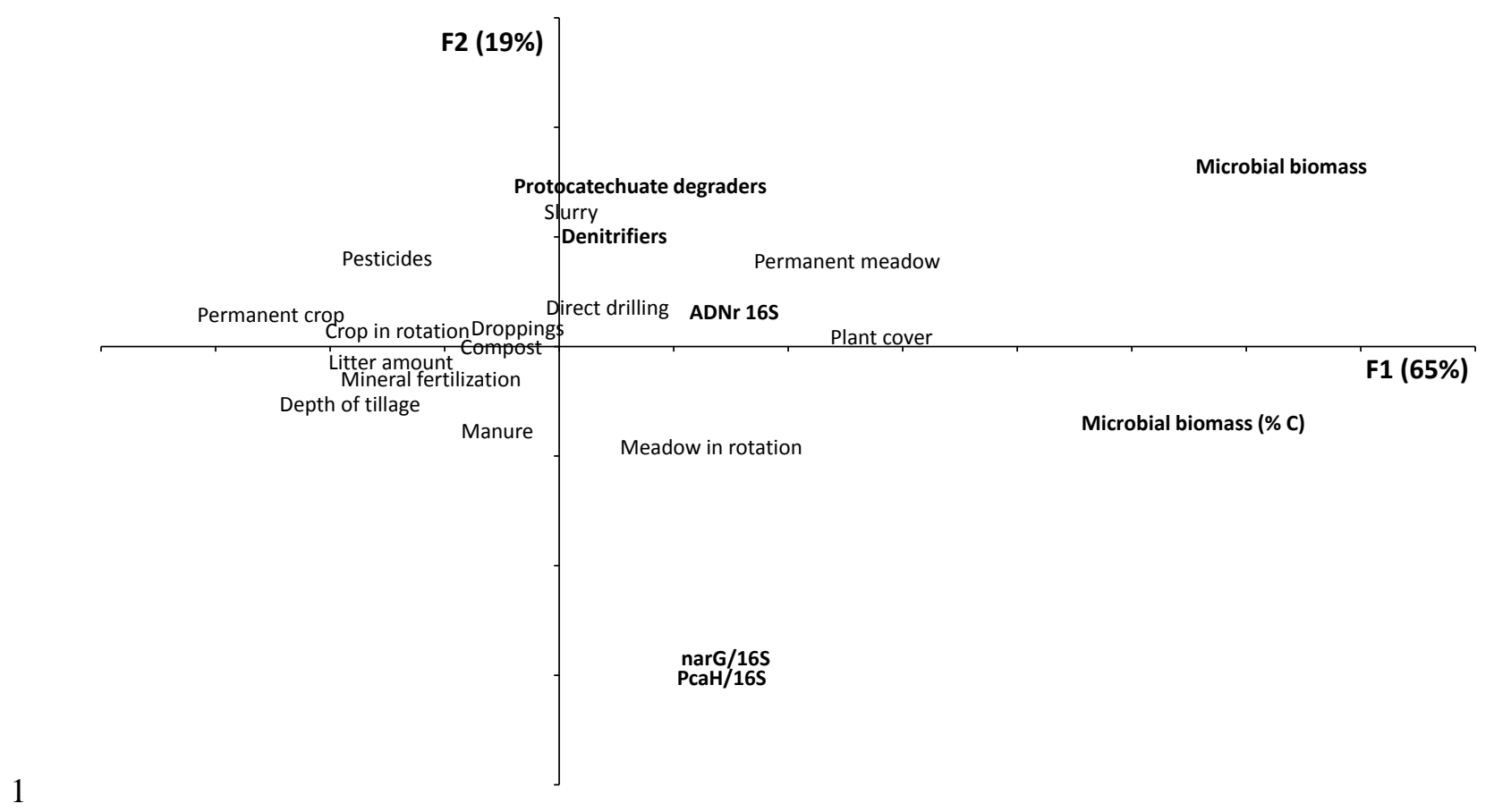

2 Fig. 5 


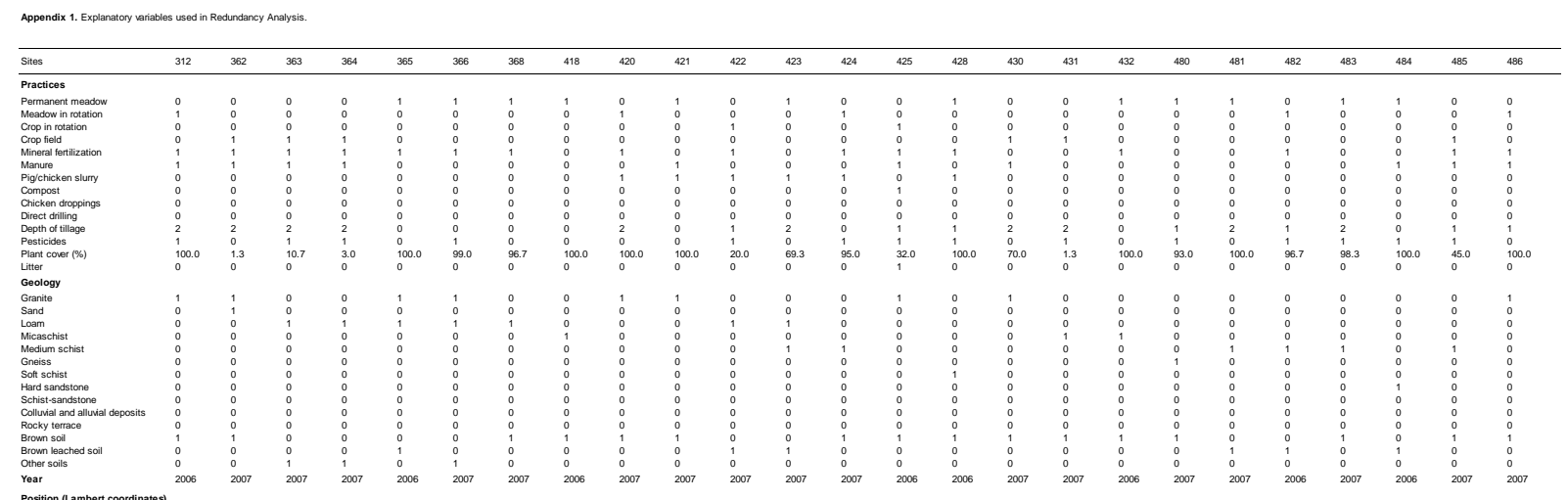

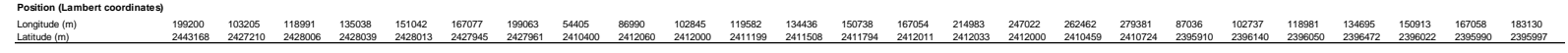
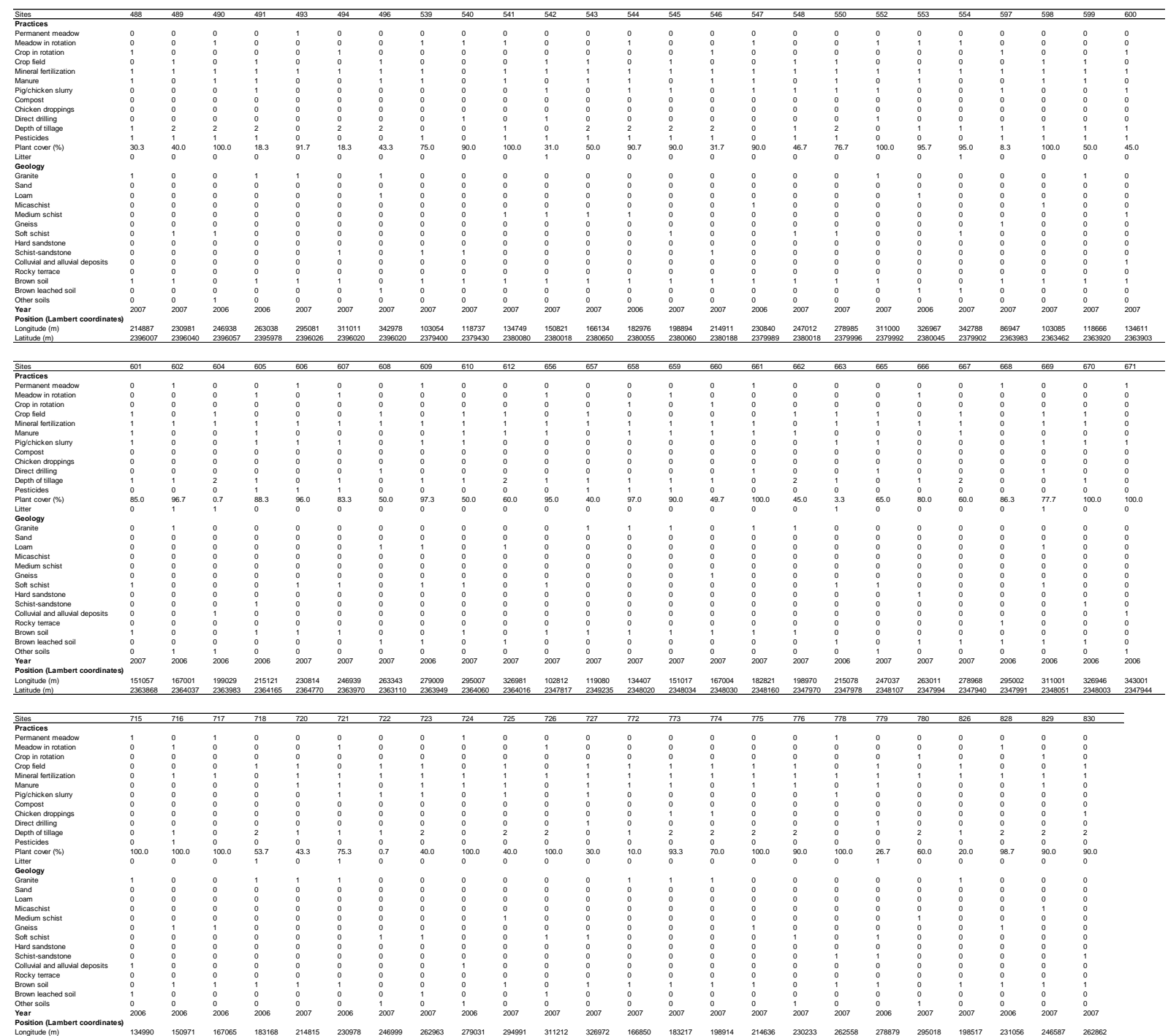
Appendix 2. List of biological variables used in Redundancy Analysis. For animal species, abundances per site were used in the analysis.

\begin{tabular}{|c|c|c|c|c|c|}
\hline Earthworms & Macrofauna other than earthworms & Microarthropods & Nematodes & Microbes & Humus Index \\
\hline Dendrobaena mammalis & Coleoptera Elateridae (adults) & Arrhopalites sp. & Achromodoridae & Microbial biomass (mg C.kg-1) & Mean Humus Index \\
\hline Dendrobaena octaedra & Coleoptera Elateridae (larvae) & Bourletiella hortensis & Alaimidae & Microbial biomass (\% total C) & Surface Humus Index \\
\hline Dendrobaena pygmea cognettii & Coleoptera Staphylinidae (adults) & Brachystomella parmila & Anatonchidae & ADNr $16 \mathrm{~S}$ & \\
\hline Dendrobaena rubida rubida & Coleoptera Curculionidae (adults) & Ceratophysella denticulata & $\begin{array}{l}\text { Anguinidae } \\
\text { A }\end{array}$ & Denitrifiers (narG) & \\
\hline Eisenia eiseni & Coleoptera Curculioinidae (larvae) & Cryptopygus bipunctatus & Aphelenchidae & narG/16S & \\
\hline Eiseniella tetraedra & Coleoptera Coccinellidae (adults) & Cryptopygus thermophilus & Aphelenchoididae & Protocatechuate degraders $(\mathrm{PcaH})$ & \\
\hline Lumbricus castaneus & Coleoptera Chrysomelidae (adults) & Desoria sp. & Aporcelaimidae & $\mathrm{PcaH} / 16 \mathrm{~S}$ & \\
\hline Lumbricus centralis & Coleoptera Cantharidae (lavae) & Entomobrya sp. & Bastianiidae & & \\
\hline Lumbricus festivus & Coleoptera Carabidae (adults) & Folsomia candida & Belondiridae & & \\
\hline Lumbricus friendi & Coleoptera Carabidae (lanvae) & Folsomia fimetaria & Belonolaiminae & & \\
\hline Lumbricus rubellus castanoides & Coleoptera Scarabaeidae (adults) & Folsomia quadrioculata & Cephalobidae & & \\
\hline $\begin{array}{l}\text { Lumbricus rubellus rubellus } \\
\text { L }\end{array}$ & Coleoptera Scarabaeoidea (lavae) & $\begin{array}{l}\text { Folsomia sexoculata } \\
\text { als }\end{array}$ & Chromadoridae & & \\
\hline Lumbricus terrestris & Coleoptera miscellaneous (adults) & Folsomia sp. & Criconematidae & & \\
\hline Nicodrilus caliginosus caliginosus trapezoides & Coleoptera miscellaneous (nymphs) & Folsomia thalassophila & Desmodoridae & & \\
\hline Nicodrilus caliginosus caliginosus typica & Coleoptera miscellaneous (larvae) & $\begin{array}{l}\text { Friesea mirabilis } \\
\text { S }\end{array}$ & Diphterophoridae & & \\
\hline Nicodrilus caliginosus meridionalis & Hymenoptera Formicidae (adults) & Heteromurus major & Diplogasteridae & & \\
\hline Nicodrilus caliginosus tuberculata & Hymenoptera miscellaneous (nymphs) & Heteromurus nitidus & Diplopeltidae & & \\
\hline Nicodrilus giardi & Hemiptera Aphidoidea (adults) & Hypogastrura sp. & Discolaimidae & & \\
\hline Nicodrilus longus longus & Hemiptera Heteroptera (adults) & $\begin{array}{l}\text { Isotoma sp. } \\
\text { Inp. }\end{array}$ & Dorylaimoidea & & \\
\hline Nicodrilus nocturnus & Hemiptera miscellaenous (adults) & Isotomodes productus & Heteroderidae & & \\
\hline Octolasium cyaneum & Dermaptera & Isotomodes trisetosus & Hoplolaimidae & & \\
\hline Earthworm abundance & Lepidootera (larvae) & Isotomiella minor & Leptolaimidae & & \\
\hline Earthworm biomass & Trichoptera (larvae) & Isotomurus antennalis & Leptonchidae & & \\
\hline Anecic abundance & Diptera Tipulidae (larvae) & Isotomurus gr. palustris & Longidoridae & & \\
\hline Endogeic abundance & Diptera miscellaneous (lavae) & Jeniddctus cyaneus & Meloidgryne & & \\
\hline Epigeic abundance & Diptera (pupae) & Lepidocyrtus lanuginosus & Monhysteridae & & \\
\hline Epreic adunadice & (Ipthontera (adults) & tenideyutus lignorum & 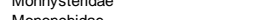 & & \\
\hline $\begin{array}{l}\text { Anecic biomass } \\
\text { Endogeic biomass }\end{array}$ & Orthoptera (adilts) & Lepiaocyrtus lignorum & Mononnchidae & & \\
\hline Endogeic biomass & Diplopoda lulidae & Megalothorax minimus & Neodiplogasteridae / Monhysteridae & & \\
\hline Epigeic biomass & Diplopoda Polydesmidae & Mesaphorura sp. & Nordilidae & & \\
\hline Earthworm taxonomic richness & Diplopoda Glomeridae & Mesaphorura florae & Nygolaimidae & & \\
\hline \multirow{43}{*}{$\begin{array}{l}\text { Earthworm diversity } \\
\text { Earthworm evenness }\end{array}$} & Diplopoda miscellaenous & Mesaphorura hylophila & Odontolaimidae & & \\
\hline & Chilopoda Lithobiomorpha & Mesaphorura italica & Odontopharyngidae & & \\
\hline & Chilopoda Geophilomorpha & Mesaphorura krausbaueri & Osstellidae & & \\
\hline & Chilopoda Scolopendromorpha & Mesaphorura macrochaeta & Panagrolaimidae & & \\
\hline & Araneae Thomisidae & Mesaphorura sylvatica & $\begin{array}{l}\text { Paratylenchidae } \\
\text { Pas }\end{array}$ & & \\
\hline & Araneae miscellaneous & Micranurida sensillata & $\begin{array}{l}\text { Plectidae } \\
\text { Plidae }\end{array}$ & & \\
\hline & Opiliones & $\begin{array}{l}\text { Micranurita sensiliara } \\
\text { Monobella grassei }\end{array}$ & Pratylenchidae & & \\
\hline & Pseudsceminoida & Mucresomia garretti & $\begin{array}{l}\text { Pratylenchidace } \\
\text { Prismatomiden }\end{array}$ & & \\
\hline & Pseudoscorpionida & Mucrosomia garretti & Prismatolaimidae & & \\
\hline & Isopoda & Mucrosomia garretti & Qudsianematidae & & \\
\hline & Gastropoda Arionidae & Orchesella sp. & Rhabditidae & & \\
\hline & Gastropoda Agriolimacidae & Paratullbergia callipygos & Rhabdolaimidae & & \\
\hline & Gastropoda miscellaneous (slugs) & Parisotoma notabilis & Steinemematidae & & \\
\hline & Gastropoda miscellaneous (snails) & Proisotoma admaritima & Telotylenchidae & & \\
\hline & Macrofauna abundance & Proisotoma minima & Teratocephalidae & & \\
\hline & Macrofauna richness & Proisotoma minuta & Thornenematidae & & \\
\hline & Phytophage abundance & Protaphorura armata & Trichodoridae & & \\
\hline & Saprophage abundance & Protaphorura subuliginata & Tripylidae & & \\
\hline & $\begin{array}{l}\text { Predator abundance } \\
\text { Proce }\end{array}$ & Pseudosinella alba & Tylenchidae & & \\
\hline & & Pseudosinella immaculata & Maturity Index (MI) & & \\
\hline & & Sminthurides malmgreni & Maturity Index without phytoparasites & & \\
\hline & & Sminthurides parulus & Bacterivore Maturity Index (BaMI) & & \\
\hline & & Sminthurides sp. & Fungivore Maturity Index (FuMI) & & \\
\hline & & Sminthurinus aureus & Nematode Channel Ratio (NCR) & & \\
\hline & & Sminthurinus elegans & Plant Parasite Index (PPI) & & \\
\hline & & Sminthurinus niger & Enrichment Index (EI) & & \\
\hline & & Sminthurus viridis & Structure Index (SI) & & \\
\hline & & Sphaeridia pumilis & Nematode Damage Index (IP) & & \\
\hline & & Stenaphorura denisi & Decomposition Index (Cl) & & \\
\hline & & Stenaphorura quadrispina & Bacterivores c-p 1 (Ba1) & & \\
\hline & & Xenyllodes armatus & Bacterivores c-p 2-3-4 (Ba234) & & \\
\hline & & Total mesofauna & Bacterivores & & \\
\hline & & Total springtails & Fungivores & & \\
\hline & & Epigeic springtails & Omnivores & & \\
\hline & & Hemiedaphic springtails & Carnivores & & \\
\hline & & Euedaphic springtails & Plant-feeders & & \\
\hline & & Total mites & Root-hair feeders & & \\
\hline & & Total oribatid mites & Total nematodes & & \\
\hline & & Total gamasid mites & Free nematodes & & \\
\hline & & Total actinedid mites & Phytoparasites & & \\
\hline & & Total acaridid mites & Nematode taxonomic richness & & \\
\hline & & Mesofaunal taxonomic richness & Nematode diversity & & \\
\hline & & Mesofaunal diversity & Nematode evenness & & \\
\hline
\end{tabular}


Appendix 3. Mean values of physico-chemical variables $\left({ }^{*}\right)$ according to land use (meadows and crop fields, permanent or in rotation) and slurry application (in permanent crop fields). Confidence levels are indicated for Kruskal-Wallis test (for land use) and Mann-Whitney tests (for slurry application): $\mathrm{NS}=$ not significant; ${ }^{*}=\mathrm{P}<0.05 ;{ }^{* *}=$ $\mathrm{P}<0.01 ;{ }^{\star \star \star}=\mathrm{P}<0.001 ;{ }^{\star \star \star \star}=\mathrm{P}<0.0001$. Upperscript letters indicate significant differences among means.

\begin{tabular}{|c|c|c|c|c|c|c|c|c|}
\hline & $\begin{array}{l}\text { Permanent } \\
\text { meadow }\end{array}$ & $\begin{array}{l}\text { Meadow in } \\
\text { rotation }\end{array}$ & $\begin{array}{l}\text { Crop in } \\
\text { rotation }\end{array}$ & $\begin{array}{l}\text { Permanent } \\
\text { crop }\end{array}$ & & Slurry & No slurry & \\
\hline & $n=23$ & $n=23$ & $n=11$ & $n=42$ & & $n=15$ & $n=27$ & \\
\hline Sand $(\%)$ & $314 \pm 28$ & $314 \pm 28$ & $340 \pm 45$ & $292 \pm 24$ & NS & $208 \pm 33^{b}$ & $338 \pm 30^{\mathrm{a}}$ & 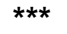 \\
\hline Silt $(\%)$ & $516 \pm 27$ & $504 \pm 26$ & $478 \pm 39$ & $525 \pm 21$ & NS & $561 \pm 33$ & $505 \pm 27$ & NS \\
\hline Clay $(\% \circ)$ & $169 \pm 5$ & $182 \pm 9$ & $182 \pm 18$ & $183 \pm 10$ & NS & $231 \pm 21^{a}$ & $157 \pm 8^{\mathrm{b}}$ & $\star \star \star \star ~$ \\
\hline Organic carbon $(\%)$ & $30.4 \pm 2.0^{\mathrm{a}}$ & $25.5 \pm 2.0^{\mathrm{ab}}$ & $30.2 \pm 2.5^{\mathrm{a}}$ & $22.0 \pm 1.6^{b}$ & 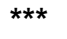 & $21.7 \pm 1.9$ & $22.3 \pm 2.2$ & NS \\
\hline Total nitrogen $(\%)$ & $2.77 \pm 0.15^{\mathrm{a}}$ & $2.38 \pm 0.18^{\mathrm{ab}}$ & $2.71 \pm 0.20^{\mathrm{ab}}$ & $2.10 \pm 0.12^{b}$ & ** & $2.27 \pm 0.17$ & $2.00 \pm 0.16$ & NS \\
\hline $\mathrm{C} / \mathrm{N}$ & $10.9 \pm 0.3$ & $10.7 \pm 0.2$ & $11.2 \pm 0.4$ & $10.3 \pm 0.2$ & NS & $9.5 \pm 0.2^{b}$ & $10.7 \pm 0.3^{\mathrm{a}}$ & ** \\
\hline Water $\mathrm{pH}$ & $5.65 \pm 0.07^{b}$ & $6.13 \pm 0.09^{\mathrm{a}}$ & $5.93 \pm 0.13^{\mathrm{ab}}$ & $6.01 \pm 0.11^{\mathrm{ab}}$ & ** & $5.98 \pm 0.10$ & $6.02 \pm 0.17$ & NS \\
\hline Cation exchange capacity $(\mathrm{cmol} / \mathrm{kg})$ & $7.19 \pm 0.52$ & $7.94 \pm 0.44$ & $8.55 \pm 0.84$ & $7.04 \pm 0.34$ & NS & $7.29 \pm 0.39$ & $6.90 \pm 0.49$ & NS \\
\hline Olsen P $(\% 0)$ & $0.084 \pm 0.011^{b}$ & $0.097 \pm 0.013^{\mathrm{ab}}$ & $0.118 \pm 0.016^{\mathrm{ab}}$ & $0.132 \pm 0.009^{\mathrm{a}}$ & ** & $0.121 \pm 0.013$ & $0.138 \pm 0.012$ & NS \\
\hline Plant cover (\%) & $96.7 \pm 1.4^{\mathrm{a}}$ & $93.0 \pm 1.7^{\mathrm{a}}$ & $43.8 \pm 8.6^{b}$ & $48.1 \pm 4.8^{\mathrm{b}}$ & $\star \star \star \star \star$ & $50.3 \pm 8.1$ & $46.9 \pm 6.0$ & NS \\
\hline
\end{tabular}

$\left(^{*}\right)$ Data provided by Chambre d'Agriculture du Morbihan (Sylvie Tico), Chambre d'Agriculture des Côtes d'Armor (Jean-Luc Giteau), Chambre d'Agriculture du Finistère (Daniel Hanocq), Chambre d'Agriculture d'Ille-et-Vilaine (Cyril Guérillot), INRA-Orléans, Unité Infosol (Claudy Jolivet \& Line Boulonne) 